\title{
The Development Law of Mining-Induced Surface Cracks in Shallow Coal Seam Through Double Gullies Terrain: A Case Study in a Mine
}

Mingjiao Lu ( $\square$ Imj_caizi@163.com )

Xi'an University of Science and Technology https://orcid.org/0000-0002-1564-7742

\section{Xueyang Sun}

Xi'an University of Science and Technology

\section{Enke Hou}

Xi'an University of Science and Technology

\section{Cheng Li}

Key Laboratory of Coal Resources Exploration and Comprehensive Utilization Ministry of Land and Resources

\section{Yonggang Zhang}

Tongji University

\section{Research Article}

Keywords: double gullies terrain, similar material simulation, surface cracks, relative position function

Posted Date: May 18th, 2021

DOI: https://doi.org/10.21203/rs.3.rs-451859/v1

License: (c) (i) This work is licensed under a Creative Commons Attribution 4.0 International License. Read Full License 

Dear Editor:

We are sure that the manuscript has not been published or presented elsewhere in part or in entirety and is not under consideration by another journal. We have read and understood your journal's policies, and we believe that neither the manuscript nor the study violates any of these. There are no conflicts of interest to declare. If you need any further information regarding this article, please feel free to contact us as the address as below.

1mj_caizi@163.com

Thank you for your consideration. I look forward to hearing from you.

Sincerely,

Mingjiao Lu

\title{
The development law of mining-induced surface cracks in shallow coal seam through double gullies terrain: a case study in a mine
}

\author{
Mingjiao Lu ${ }^{1}$, Xueyang Sun ${ }^{1,2}$, Enke Hou ${ }^{1,2},{\text { Cheng } \mathrm{Li}^{2} \text {, Yonggang Zhang }}^{3}$ \\ 1 School of Geology and Environment, Xi' an University of Science and Technology, Xi'an 710054, China; \\ 2 Key Laboratory of Mine Geological Hazards Mechanism and Control, Xi'an 710054, China; \\ 3 Key Laboratory of Geotechnical and Underground Engineering of Ministry of Education, Department of Geotechnical \\ Engineering, Tongji University, Shanghai 200092, China.
}

\begin{abstract}
Mining-induced surface cracks in gullies in shallow seams seriously threaten the development of ecological stability and the safety of mine production. The development law of surface cracks in shallow coal seam mining through double gullies terrain was studied, by taking the Cao Jiatan coal mine in the Yushen Mining Area as a project example. The function $T$ and its discriminant were first put forward to describe the relative position both the surface cracks and working face advanced in shallow coal seam mining through double gullies terrain. The relationship between valley parameters of double gullies terrain and the relative position of surface cracks development was discussed through numerical simulation experiment, similar material simulation experiment and theoretical analysis. The results showed that when the working face passed through the G1 gully, the development of surface cracks led the working face. There were four surface cracks with a maximum width of $23 \mathrm{~cm}$, and the maximum vertical displacement was $11 \mathrm{~cm}$; while passing through the $\mathrm{G} 2$ gully, the development of surface cracks lagged the working face. There were seven surface cracks with a maximum width of $79 \mathrm{~cm}$, and the maximum vertical displacement was $45 \mathrm{~cm}$. It can be concluded that the relative position of crack development is greatly affected by geological conditions, gully depth, slope angle, span and other factors of the gully, among of which the gully slope angle is the main influencing factor. $T$ and $|T|$ value has a certain correlation with the lagging distance, crack width, vertical displacement and the total number of cracks in a single gully.
\end{abstract}

Keywords: double gullies terrain; similar material simulation; surface cracks; relative position function 


\section{Introduction}

Mining-induced surface cracks is a frequent cause of damage to building features, surface and underground water resources, and other environmental features [1-5]. In northwest China, the majority of mining areas are located within or on the edges of deserts, which often have shallow coal seam reserves for mining and vertical and horizontal gullies on the surface. However, these areas also have arid and semi-arid climates with fragile ecological environments and significant water shortages [6-8].

Yushen Coalfield is located in the transition zone between the Loess Plateau and the Mu Us Sandy Land with rugged topography, and a gullied surface [9], under gullies topography, mining-induced surface cracks is a severe threat to the local fragile ecological environment [10-13]. Researchers have studied the influence of valley topography on mining-induced surface cracks using numerical simulation [14-17], physical simulation [18-24], theoretical analysis [25-28] and field survey $[19,21,29,30]$. The research shows that a single slope and different slopes angle, the overburden strata load increases with the increase of the gully slope angle; and with the continuous increase of the gully depth, the dynamic pressure behaviour of the working face in the upper slope section of the gully behaves stronger [20, 31, 32]. The strenuous degree of pressure behaviour in shallow coal seam mining under the gully shows the characteristics of "back gully section > toward gully section $>$ bottom gully section $>$ normal mining section" [33]. Under the assumption that the slope in the gully is single and the slope angle is constant, the mechanical model of "non-uniform load beam" [34] can fully characterize the dynamic load process of the working face through the gully terrain [22, 35]. Remote sensing technology and field survey can effectively reveal the plane distribution law and dynamic development law of mining-induced surface cracks and their relationship with the generation progress of the working face [36].

The above studies show that the gully geomorphology has a significant influence on the mining surface cracks, especially in the shallow coal seams where loess and blown-sand exist in the topsoil. However, the studies above are mostly based on a single gully landform. At present, there is little research on the development characteristics of surface cracks in shallow coal seam mining through double gullies terrain, which needs to be studied urgently.

In this paper, FLAC3D numerical simulation, similar material simulation and theoretical analysis were used to study the development law of surface cracks caused by mining through double gullies terrain in the shallow coal seam, and the effects of gully depth, slope and span on the relative position of surface cracks were also analyzed.

\section{1 the introduction of Study area}

The surface of Cao Jiatan Coal Mine in Yushen Mining area is a typical loess beam and loess landform with a complex topography and vertical and horizontal gullies. The terrain is high in the north and low in the south, and Er Dao gully was developed in the middle. Meanwhile, the average annual rainfall is less than $500 \mathrm{~mm}$, leading to scarce water resources and fragile ecological environment. The No. 2-1 and 3-1 seams are mainly coal seam in the mine, which are generally distributed almost horizontally. The LW272106 working face is located in the northwest of the minefield, and the surface vegetation coverage of the working face is about $35 \%$. The maximum elevation located at a distance from the open-off cut of the working face is $1147 \mathrm{~m}$, while the minimum elevation located at the stopping line is $1116 \mathrm{~m}$. The $\mathrm{Er}$ Dao gully obliquely passes through the working face and approximately shows an angle of $125^{\circ}$ with the 
strike azimuth of the working face. The branches of the Er Dao gully in the working face are G1 gully and G2 gully (G1 is the secondary gully, G2 is the main gully), and the distance between the two gullies is about $70 \mathrm{~m}$. The working face is a loess beam gully landform, the bedrock is exposed at the bottom of the gully, the main mining coal seam is the No. 2-1 seam, whose thickness is $2.2 \sim 3.0 \mathrm{~m}$, the average thickness is $2.5 \mathrm{~m}$, and the burial is very shallow, the local thickness is less than $30 \mathrm{~m}$, the thickness of the roof bedrock is $20 \mathrm{~m} \sim 65 \mathrm{~m}$, and the Blown-sand and the Quaternary loose layer above the roof bedrock is $0 \sim 77$ $\mathrm{m}$. The strike length of the working face is $1152 \mathrm{~m}$, the inclination length is $240 \mathrm{~m}$, and the mining height is $2.5 \mathrm{~m}$. The comprehensive mechanized coal mining technology is adopted for mining. The mining plan of the panel and the XE28 borehole data of working face LW272106 are shown in Figure 1.

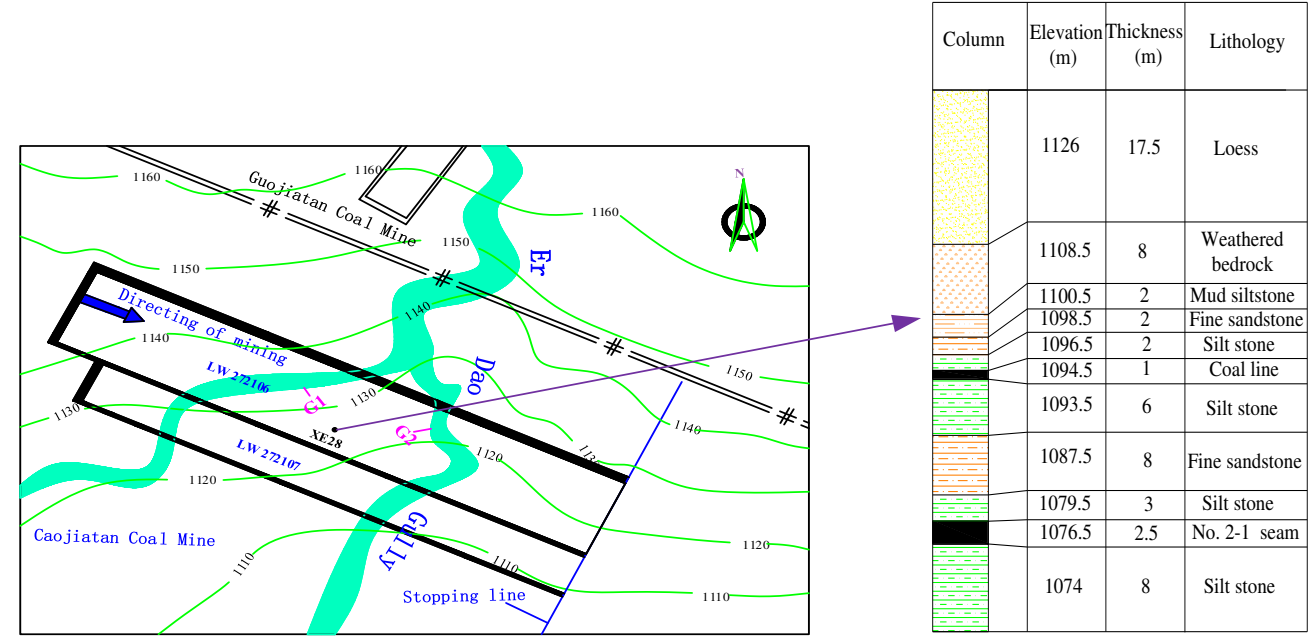

Fig.1 Plan view of the local panel layout and drill column

The mining of LW272106 working face passes through Er Dao gully, where exists seasonal running water, and rainfall in the rainy season will induce running water or flood; in other months, the gully is dry. In the mining area, the length of G2 (main gully) is about $1330 \mathrm{~m}$, and the width is about $150 \mathrm{~m} \sim 280$ $\mathrm{m}$. The length of G1 (secondary gully) is about $700 \mathrm{~m}$, and the width is about $15 \mathrm{~m} \sim 100 \mathrm{~m}$. The buried depth of the coal seam is about $20 \mathrm{~m}$, and the distance between the edges of the two gullies is $61 \mathrm{~m}$. The basic topographic parameters of Er Dao gully are shown in Table 1.

Tab. 1 Basic parameters of double gullies terrain

\begin{tabular}{cccccc}
\hline $\begin{array}{c}\text { Gully } \\
\text { name }\end{array}$ & Types & $\begin{array}{c}\text { Uphill angle }\left({ }^{\circ}\right) / \\
\text { Downhill angle }\left({ }^{\circ}\right)\end{array}$ & $\begin{array}{c}\text { Span } \\
(\mathrm{m})\end{array}$ & $\begin{array}{c}\text { Gully depth } \\
(\mathrm{m})\end{array}$ & Remarks \\
\hline G1 & Secondary gully & $31 / 21$ & 80 & 15 & $\begin{array}{c}\text { The distance between } \\
\text { the edges of the two } \\
\text { G2 }\end{array}$ \\
Main gully & $21 / 17$ & 224 & 25 & gullies: $l=61 \mathrm{~m}$ \\
\hline
\end{tabular}

\section{Numerical simulation experiment}

\subsection{Numerical model of the double gullies terrain}

Based on the LW272106 working face condition and the strata and lithology data of the XE28 drill column, a FLAC3D model with the size of $600 \mathrm{~m} \times 300 \mathrm{~m} \times 60 \mathrm{~m}$ was constructed as illustrated in Figure 2. Combining the experimental parameters of rock mechanics in the coal minefield, the variation law of overburden displacement field and the development law of surface cracks while working face passing through G1 and G2 gullies were studied. The model front, back, left, right and bottom boundaries were fixed boundary, and the top was a free boundary. In the model, mining length was $500 \mathrm{~m}$, mining width was $240 \mathrm{~m}$. The Mohr-Coulomb strength criterion was 
used to calculate the overburden stress and parameters are shown in Table 2.

deformation of the model. The main rock mechanics

Tab. 2 Mechanical parameters of the main rock

\begin{tabular}{ccccccc}
\hline Lithology & $\begin{array}{c}\text { Density } \\
\left(\mathrm{kg} / \mathrm{m}^{3}\right)\end{array}$ & $\begin{array}{c}\text { Bulk Modulus } \\
(\mathrm{MPa})\end{array}$ & $\begin{array}{c}\text { Shear Modulus } \\
(\mathrm{MPa})\end{array}$ & $\begin{array}{c}\text { Tensile strength } \\
(\mathrm{MPa})\end{array}$ & $\begin{array}{c}\text { Cohesion } \\
(\mathrm{MPa})\end{array}$ & $\begin{array}{c}\text { Friction } \\
\text { angle }\left({ }^{\circ}\right)\end{array}$ \\
\hline Loess & 1702 & 32 & 16.17 & 0.088 & 0.48 & 22 \\
Weathered bedrock & 2200 & 3250 & 990 & 0.56 & 0.56 & 36 \\
Mud siltstone & 2760 & 3006 & 1718 & 3.23 & 2.85 & 32 \\
Fine sandstone & 2750 & 3166 & 1991 & 2.92 & 3.91 & 34 \\
Silt stone & 2760 & 3187 & 1821 & 3.65 & 3.87 & 34 \\
Coal line & 1420 & 2137 & 957 & 0.25 & 2.98 & 33 \\
Silt stone & 2760 & 3187 & 1821 & 3.65 & 3.87 & 34 \\
Fine sandstone & 2750 & 3166 & 1991 & 2.92 & 3.91 & 34 \\
Silt stone & 2760 & 3187 & 1821 & 3.65 & 3.87 & 34 \\
No. 2-1 seam & 1420 & 2137 & 957 & 0.25 & 2.98 & 33 \\
Silt stone & 2760 & 3187 & 1821 & 3.65 & 3.87 & 34 \\
\hline
\end{tabular}

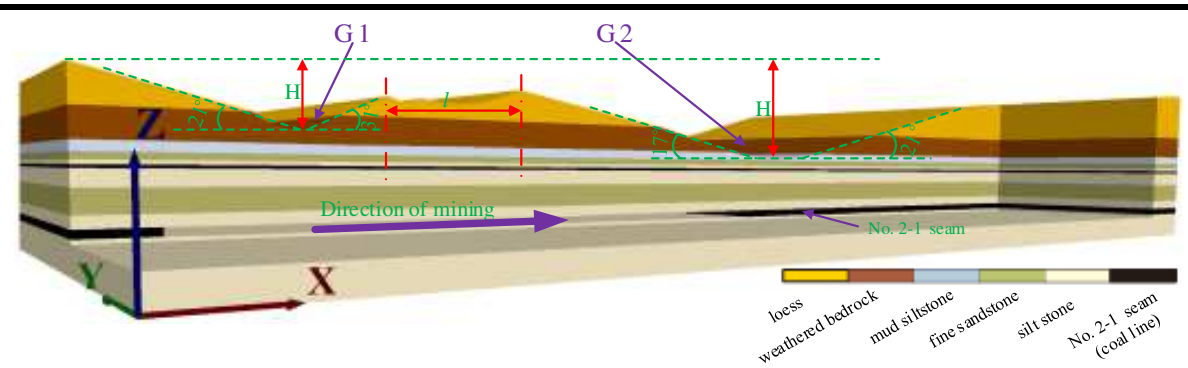

Fig.2 The numerical simulation model

\section{2 the analysis of model results}

The surface displacement field changed obviously, which was mainly shown in the development range of displacement in the $\mathrm{X}$ direction and $\mathrm{Z}$ direction when the working face (No. 2-1 seam) was located in the toward-gully section, bottom-gully section and a back-gully section of the G1 gully, as shown in figure 3. It is stipulated that the $\mathrm{X}$ direction is complimentary with the mining direction of the working face, and vice versa; the downward direction of $\mathrm{Z}$ direction is complimentary, and vice versa.

When the working face advanced to the toward-gully section of G1, due to the overburden strata falling in the goaf, the rock mass in the toward-gully section began to squeeze into the goaf, resulting in negative and positive horizontal displacements in front of and behind the work, with values of $0.5 \mathrm{~cm}$ and $2.0 \mathrm{~cm}$ respectively, and the range of overburden subsidence was small. The deformation range does not affect the surface. Among them, along with the direction of the working face advancing, the surface crack development area was located at the bottom-gully section in front of the working face, and the centre of the crack development area was advanced $9 \mathrm{~m}$ ahead of the working face. As shown in Figure 3 (a).

When the working face advanced to the bottom-gully section, the range of the development area of the surface fracture was smaller than that of the toward-gully section, and the negative and positive horizontal displacement in front of the work gradually increased, the subsidence range of overburden strata gradually expanded to $35 \mathrm{~cm}$. The surface crack development area was located in the back-gully section, and the centre of the crack development area was advanced $7 \mathrm{~m}$ ahead of the working face. These 
phenomena occurred because the depth of the G2 gully was more significant than the G1 gully, the overburden strata of the back-gully section of the gully continued to squeeze to the goaf at the bottom-gully section, and the overburden stress of the back-gully section of G1 was partially distributed to the toward-gully section of G2, as shown in Figure 3 (b).

When the working face advanced to the back-gully section of the G1 gully, the positive horizontal displacements in the back-gully section of G1 gully was $1.4 \mathrm{~cm}$. The negative directions of the toward-gully section of the G1 gully were $2.4 \mathrm{~cm}$, and the range of surface cracks began to increase. Due to the influence of the depth gully and the slope of the toward-gully section of the G2 gully, and the compression of the rock mass on both sides of the gully on the G1 gully. The subsidence range of overburden strata was broad, and the surface subsidence value increased to $85 \mathrm{~cm}$. Among them, the surface crack development area along with the direction of working face advancing was located at the sharp corner of the toward-gully section of the gully in front of the working face, and the centre of the crack development area was advanced $6 \mathrm{~m}$ ahead of the working face. As shown in Figure 3 (c).

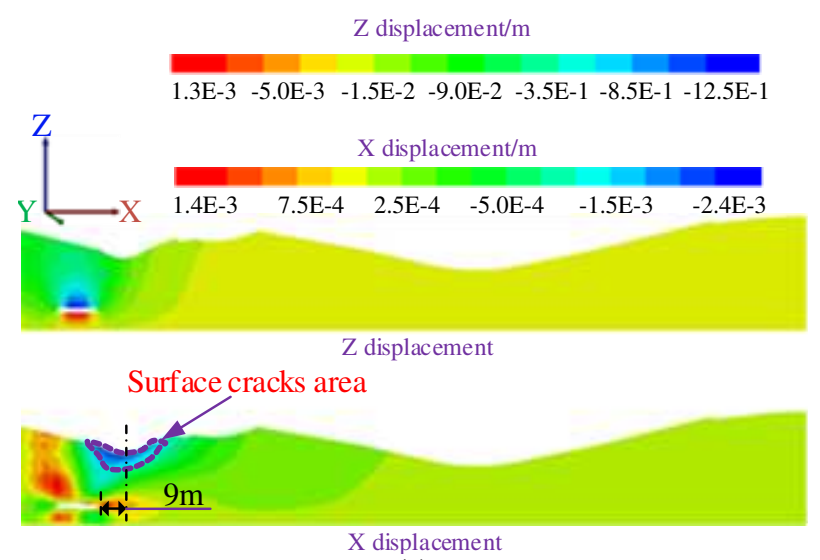

(a)
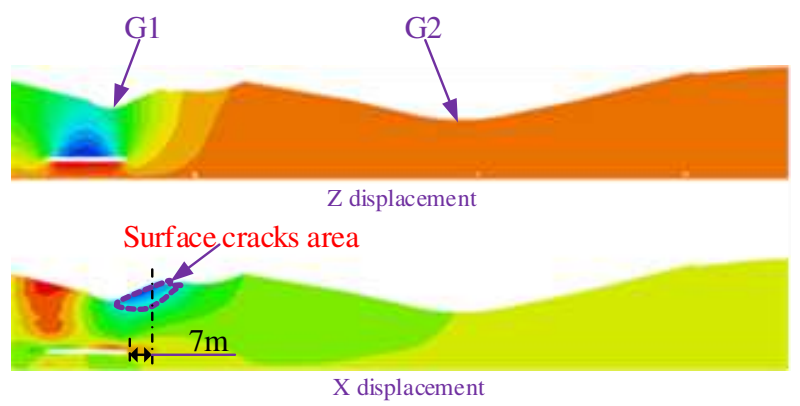

(b)

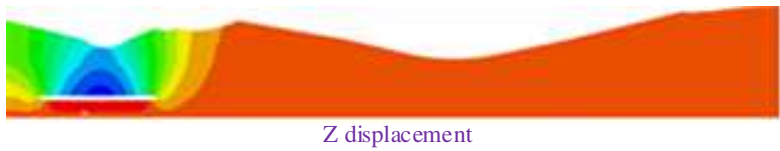

Surface cracks area

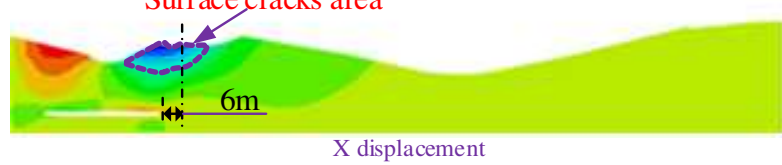

(c)

Fig.3 Displacement cloud map of overburden strata passing through G1 gully. (a) Toward-gully section. (b) Bottom-gully section. (c) Back-gully section.

When the working face advanced to the influence area of the main gully (G2), due to the close distance between the G2 gully and the G1 gully, the movement of the overburden strata in the toward-gully section of the G1 gully toward the goaf, the depth of the G2 gully was greater than that of G1. The stress redistribution of the overburden strata, the overburden strata of the G2 gully was subjected to double tensile stress. The horizontal movement area and vertical subsidence range of the overburden strata were different from those of the G1 gully, as shown in Figure 4.

When the working face advanced to the toward-gully section because the overburden strata of the goaf cross and fell, the rock mass of the toward-gully section was squeezed to the goaf. The influence of the G1 back-gully section on the G2 toward-gully section was intensified, so the rock strata of the G2 toward-gully section were subjected to the joint action of tensile stress in both left and right directions, leading a large negative horizontal displacement of $5.0 \mathrm{~cm}$ in the toward-gully section behind the working face. In the range of G1 gully, the 
horizontal displacement size was $4.0 \mathrm{~cm}$ in a positive direction. The maximum subsidence value of the surface was $155 \mathrm{~cm}$, and the deformation range extends to the surface. The subsidence range of overburden strata is located in the middle of the goaf. Among them, the surface crack development area along with the advance of the working face is located in the toward-gully section behind the working face, and the centre of the crack development area lags behind the advance of the working face by $18 \mathrm{~m}$. As shown in figure 4 (a)

when the working face advances to the bottom of the valley, because the influence of the toward-gully section of the G1 gully on the downslope section of the G2 gully gradually weakens, and the working face gradually moves away from the secondary gully G1, the range of negative horizontal displacement developed at the bottom of the gully decreases gradually, and the positive horizontal displacement within the range of the G1 gully begins to decrease. The subsidence range of overburden strata increases gradually. Among them, the surface crack development area with the advance of the working face is located at the bottom of the gully, and the centre of the crack development area lags behind the advance of the working face by $7 \mathrm{~m}$. As shown in figure 4 (b).

When the working face advanced to the back-gully section of the G2 gully, the influence of the G2 gully on the G1 gully decreased gradually because the working face gradually moved away from the G1 gully, so that the range of horizontal movement and value of G1 decreased gradually. The negative horizontal displacement developed in the back-gully section of the gully. The positive displacement in the G1 gully decreased to $3.5 \mathrm{~cm}$. The subsidence range of overburden strata was further expanded, and the surface subsidence value decreased slightly. Among them, the surface crack development area along with the direction of the working face advancing was located in the back-gully section of the valley behind the working face, and the centre of the crack development area lagged behind the advance of the working face by $13 \mathrm{~m}$ as shown in Figure 4 (c).

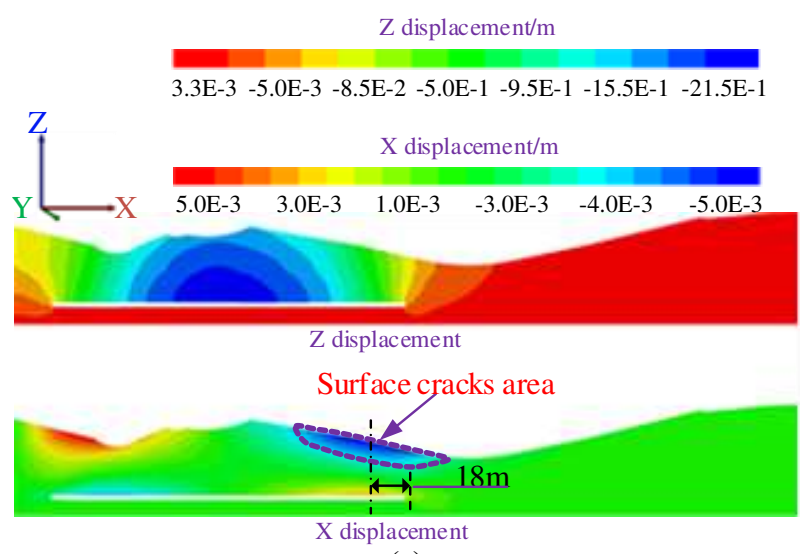

(a)

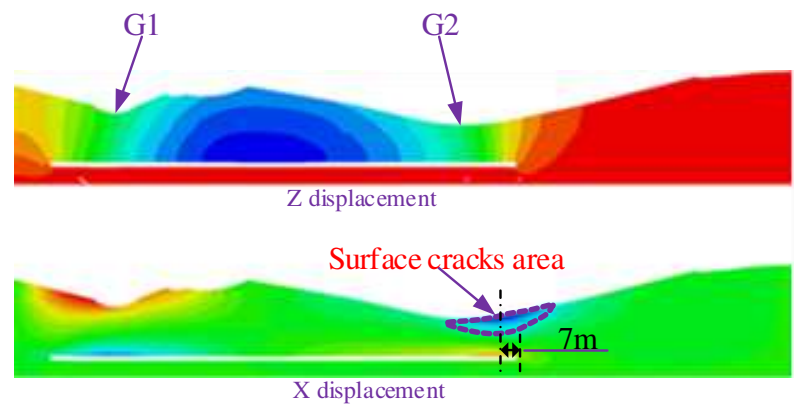

(b)

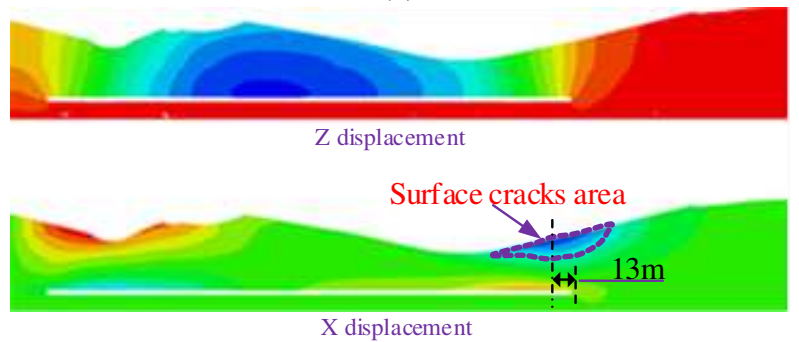

(c)

Fig.4 Displacement cloud map of overburden strata passing through G2 gully. (a) Toward-gully section. (b) Bottom-gully section. (c) Back-gully section.

To sum up, when the No. 2-1 seam mining face passed through the double gullies terrain, the surface crack development area ahead of the working face when the working face passed through the G1 gully, and the influence of the G2 gully and G1 gully was small. When the working face passed through the G2 gully, the surface crack development area lagged behind the working face, and the interaction between 
the G1 gully and the G2 gully was more significant than the working face passes through its toward-gully section. However, when the working face passed through its bottom-gully section and back-gully section, the interaction between the G1 gully and the G2 gully gradually decreased.

\section{Similar material simulation experiment}

\subsection{Model design}

In order to obtain the detailed development characteristics and dynamic development process of surface cracks in working face mining passing through double gullies terrain, a two-dimensional model framework of $4000 \mathrm{~mm}$ in length, $200 \mathrm{~mm}$ in width, and $600 \mathrm{~mm}$ in height were selected to build a physical model based on similarity theory. The model should meet the primary similarity conditions, such as similarity of geometry, time, weight, elastic modulus, and strength. Following similarity criteria, similar simulation coefficients were obtained as follows:

(a) Geometric similarity ratio

Supposing the geometric dimensions of each rock stratum in the prototype and corresponding stratum in the model are $x_{m}$ and $x_{r}$ (or $y_{m}$ and $y_{r}$ ), respectively. The geometric similarity ratio is:

$$
a_{l}=\frac{x_{m}}{x_{r}}=\frac{y_{m}}{y_{r}}=1 / 100
$$

(b) Similarity ratio of Poisson's ratio

It was assumed that Poisson's ratios of each rock stratum in the prototype and corresponding stratum in the model were $\mu_{p}$ and $\mu_{m}$, thus:

$$
a_{\mu}=\frac{\mu_{m}}{\mu_{p}}=1
$$

(c) Similarity ratio of bulk density

When the densities of each rock stratum in the prototype and corresponding stratum in the model were assumed to be $r_{m}$ and $r_{r}$, respectively. the density similarity coefficient was:

$$
a_{r}=\frac{r_{m}}{r_{r}}=1 / 1.6
$$

(d) Similarity ratio of elastic modulus

It was supposed that the elastic moduli of each rock stratum in the prototype and corresponding stratum in the model were $E_{p}$ and $E_{m}$, so the elastic modulus similarity coefficient was:

$$
a_{\sigma}=\frac{E_{m}}{E_{p}}=a_{r} \times a_{l}=1 / 160
$$

(e) Similarity ratio of time

The time similarity coefficient was expressed as follows by assuming the mining time for coal seams in the prototype and the coal seam in the model as $C_{L}$ and $C_{t}$.

$$
a_{t}=\sqrt{a_{l}}=1 / 10
$$

(f) Similarity ratio of strength

The strength similarity coefficient was expressed as by assuming the compressive strengths of each rock stratum in the prototype and the corresponding stratum in the model as $\sigma_{p}$ and $\sigma_{m}$,

$$
a_{\sigma}=\frac{\sigma_{m}}{\sigma_{p}}=a_{r} \times a_{l}=1 / 160
$$

To establish the physical model, river sand, lime, gypsum, oil and water were selected as necessary materials. Through multiple uniaxial compression tests on the samples mixed in different ratios, the optimum mix of the materials was determined. In

\begin{tabular}{|c|c|c|c|c|c|c|c|c|}
\hline \multirow{2}{*}{ Strata type } & \multirow{2}{*}{$\begin{array}{c}\text { Strata } \\
\text { thickness (m) }\end{array}$} & \multirow{2}{*}{$\begin{array}{c}\text { Model } \\
\text { thickness }(\mathrm{mm})\end{array}$} & \multirow{2}{*}{$\begin{array}{c}\text { Simulated material } \\
\text { proportioning } \\
\text { quality }(\mathrm{kg})\end{array}$} & \multicolumn{5}{|c|}{ Simulated material ratio } \\
\hline & & & & Sand & Gypsum & Lime & Loess & Oil \\
\hline
\end{tabular}
addition, mica powder was sprinkled between the layers. The key physic mechanical parameters of coal rocks and relevant ratios of similar materials were listed in Table 3.

Tab. 3 Material selection and matching 


\begin{tabular}{|c|c|c|c|c|c|c|c|c|}
\hline Loess & 17.5 & 175 & 96.00 & 4.5 & & & 4.5 & 1 \\
\hline Weathered bedrock & 8 & 80 & 102.40 & 8 & 2 & 8 & & \\
\hline Mud siltstone & 2 & 20 & 25.60 & 7 & 2 & 8 & & \\
\hline Fine sandstone & 2 & 20 & 25.60 & 7 & 3 & 7 & & \\
\hline Silt stone & 2 & 20 & 25.60 & 7 & 3 & 7 & & \\
\hline Coal line & 1 & 10 & 12.80 & & & & & \\
\hline Silt stone & 6 & 60 & 76.80 & 7 & 3 & 7 & & \\
\hline Fine sandstone & 8 & 80 & 102.40 & 7 & 3 & 7 & & \\
\hline Silt stone & 3 & 30 & 38.40 & 7 & 3 & 7 & & \\
\hline No. 2-1 seam & 2.5 & 25 & 32.00 & & & & & \\
\hline Silt stone & 8 & 80 & 102.40 & 7 & 3 & 7 & & \\
\hline Total & 60 & 600 & 640.00 & & & & & \\
\hline
\end{tabular}

The establishment of the physical model was carried out using similar materials, and the process can be divided into five steps: weighing materials, mixing materials, adding water and uniformly mixing, placing and tamping, and natural air drying. Finally, the total height was $600 \mathrm{~mm}$, as shown in Figure 5.

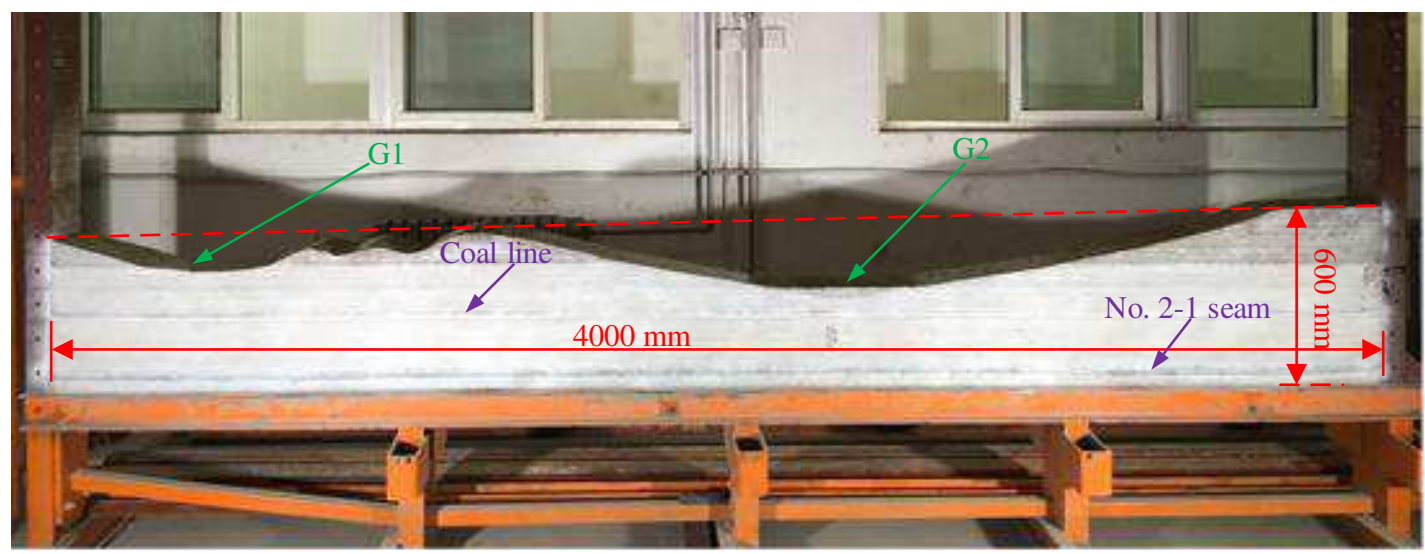

Fig.5 Similar material simulation model

The similar material simulation experiment was used to simulate the working face passing through the double gullies terrain, and development position, shape and parameters of surface cracks under were recorded. Because the supplementary numerical simulation experiment can not fully reflect the disadvantages of the development characteristics and dynamic development process of surface cracks, According to the lithology and structure characteristics of strata in LW272106 working face, a two-dimensional similar material simulation model with a similarity ratio of 1: 100 was established. The total thickness of the simulated strata was about $60 \mathrm{~m}$. Because of the effect of the topography, the maximum thickness of overburden in No. 2-1 seam was $47 \mathrm{~m}$, while the minimum thickness of overburden was $20 \mathrm{~m}$. Layered modelling was carried out according to the ratio of similar materials, and the size of the model was length $\times$ height $\times$ width $=400 \times 60 \times 20 \mathrm{~cm}$. The terrain conditions such as toward-gully, bottom-gully and back-gully were designed to simulate mining. The parameters of the gully are listed in Table 1. During the experiment, the VIC-3D digital speckle method was used to monitor the overburden displacement of 
the working face while mining through G1 and G2 gullies.

\subsection{The development law of surface cracks}

The results of similar material simulation experiment showed that the surface crack was a dynamic process from development to stability.

In the process of mining through the G1 gully in the working face, the surface crack was a tensile crack at the initial stage of the development. After the development of the surface, cracks became stable, there were two surface cracks in the toward-gully, and the types of cracks were shear type and tensile type respectively which were $25 \mathrm{~m}$ and $30 \mathrm{~m}$ away from the open-off cut and advance working face $5 \mathrm{~m}$ and $10 \mathrm{~m}$. There was a compressive crack at the bottom-gully, which was $60 \mathrm{~m}$ and $20 \mathrm{~m}$ away from the open-off cut and advanced working face, respectively. In the back-gully, there was a tensile crack, which was $93 \mathrm{~m}$ and $13 \mathrm{~m}$ away from the open-off cut and advanced working face, respectively. Among them, the maximum crack whose width was $23 \mathrm{~cm}$ and vertical displacement was $11 \mathrm{~cm}$ appeared in the toward-gully section. In this process, the surface cracks shape, development location, crack width and vertical displacement were shown in Figure 6(a) and (c). The measured results of overburden displacement were shown in Figure 6(b). it was illustrated that the negative maximum horizontal displacement was $2.3 \mathrm{~cm}$ in the back-gully section, and the positive maximum horizontal displacement was $2.5 \mathrm{~cm}$ in the toward-gully section. The maximum subsidence value $93 \mathrm{~cm}$ of the ground surface appeared in the bottom-gully section. Compared with the numerical simulation results in Figure 3(c), the simulation results of similar materials were in good agreement with the numerical simulation results.

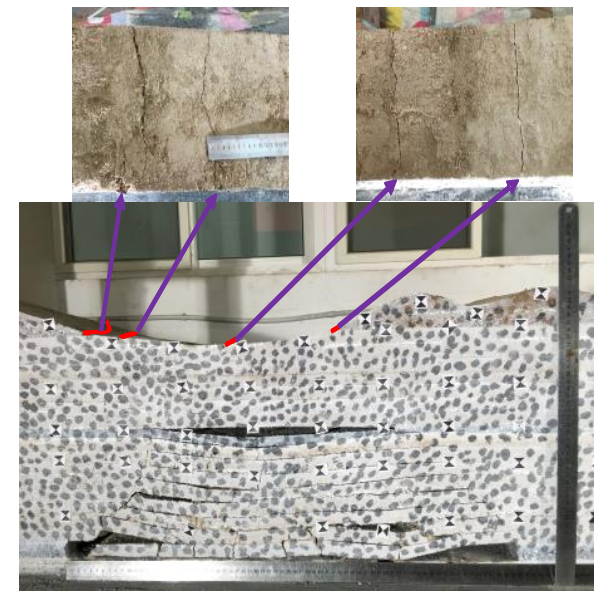

(a)
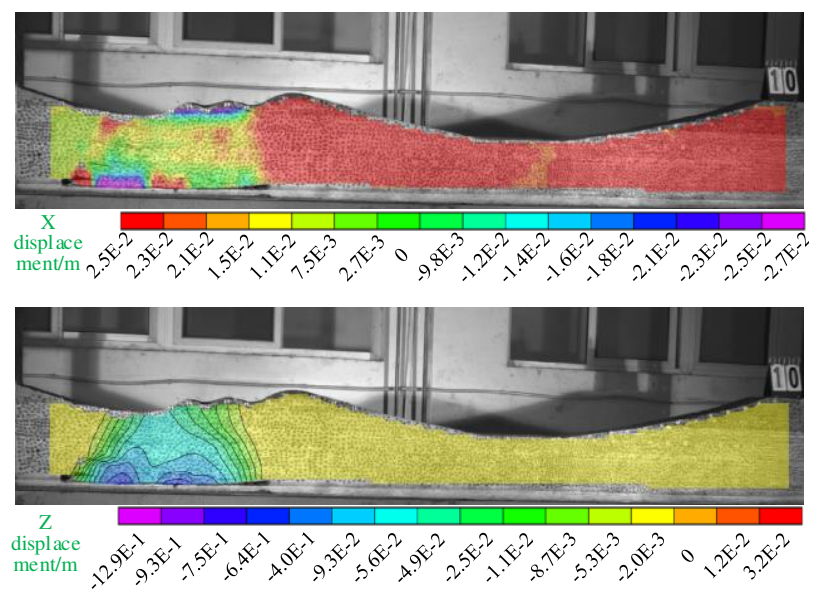

(b)

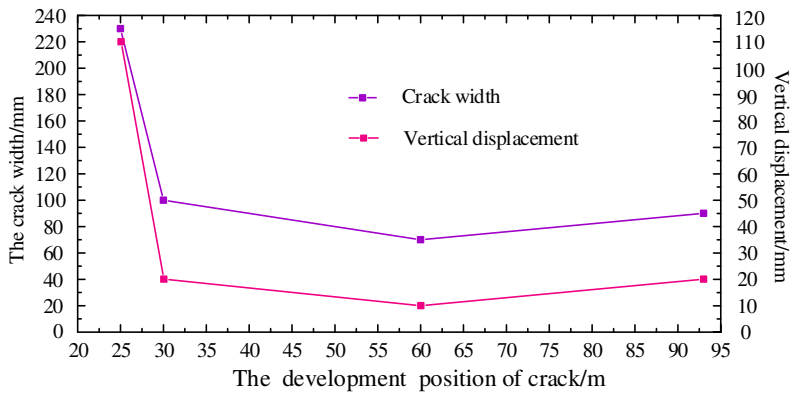

(c)

Fig.6 Morphology and parameters of surface cracks passing through G1 gully. (a) Development morphology of surface cracks. (b) Displacement cloud map of overburden strata (VIC-3D). (c) Development position of surface cracks.

When the working face advanced to G2 gully after the surface cracks developed stably, a shear-type surface crack developed in the toward-gully section, the development position was $160 \mathrm{~m}$ away from the open-off cut, and the crack lagged $20 \mathrm{~m}$ behind the working face. There were three compressive cracks developed in the bottom-gully section, which were 
$190 \mathrm{~m}, 200 \mathrm{~m}$ and $215 \mathrm{~m}$ away from the open-off cut, and lagged $10 \mathrm{~m}, 20 \mathrm{~m}$ and $5 \mathrm{~m}$ behind the working face, respectively. There was a tensile crack in the back-gully section, $285 \mathrm{~m}$ away from the open-off cut and lagged $15 \mathrm{~m}$ behind the working face. There were two shear cracks, the development position was $335 \mathrm{~m}$ and $340 \mathrm{~m}$ away from the open-off cut, and the cracks lagged $15 \mathrm{~m}$ and $20 \mathrm{~m}$ behind the working face. Among them, due to the influence of the back-gully section of G1 on the toward-gully section of G2, the rock strata in the toward-gully section of G2 were affected by tensile stress in both left and right direction, so the maximum crack width $(79 \mathrm{~cm})$ and vertical displacement $(45 \mathrm{~cm})$ both appeared in the toward-gully section of G2. When the working face passed through G2 gully, there were seven surface cracks, including crack shape, development position, crack width and vertical displacement, as shown in Figure 7 (a) and (c). The monitoring results of overburden displacement are shown in Figure 7 (b). The maximum negative horizontal displacement was $25 \mathrm{~cm}$ in the back-gully of $\mathrm{G} 2$, the maximum positive horizontal displacement was $33 \mathrm{~cm}$ in the back-gully of G1 and G2, and the maximum surface subsidence was $162 \mathrm{~cm}$ at the bottom-gully of G1 and G2. Compared with the numerical simulation experimental results (Figure 4 (c)), the similar material simulation experimental results were in good agreement with the numerical simulation experimental results.

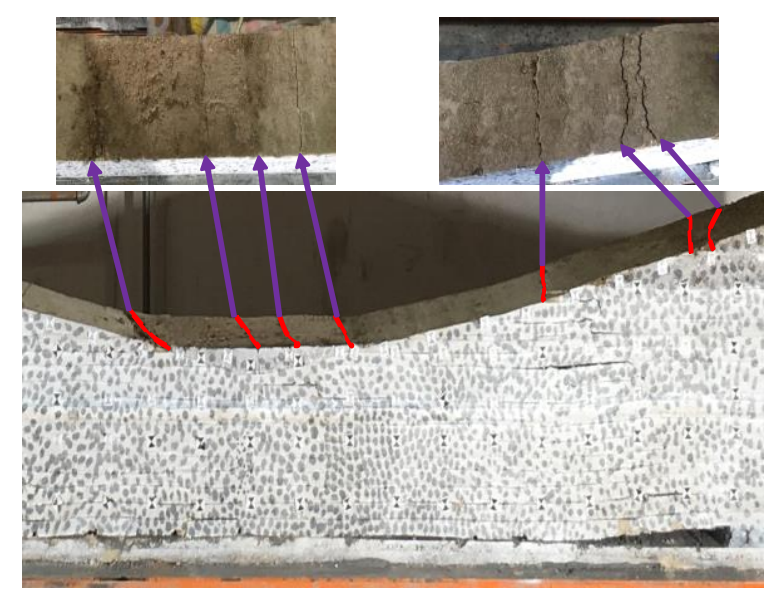

(a)
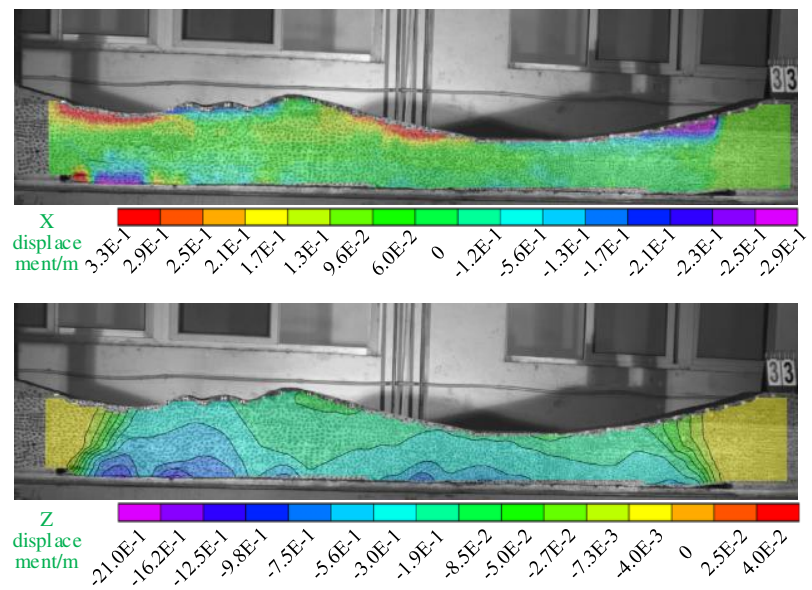

(b)

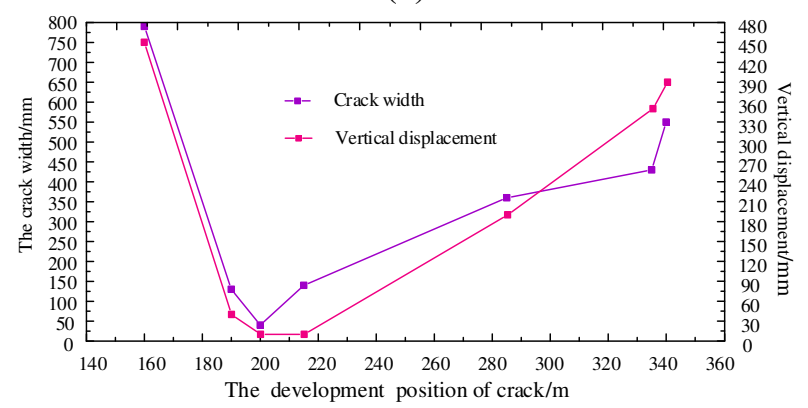

(c)

Fig.7 Morphology and parameters of surface cracks passing through G2 gully. (a) Development morphology of surface cracks (VIC-3D). (b) Displacement cloud map of overburden strata. (c) Development position of surface cracks.

To sum up, similar material simulation experiments showed that when the working face was passing through the double gullies, terrain: There were four surface cracks in the G1 gully, including two tensile types, one extrusion type and one shear type, with the maximum crack width of $23 \mathrm{~cm}$ and the maximum vertical displacement $11 \mathrm{~cm}$. The development of surface cracks was advanced of the working face, and the crack width and vertical displacement increased with the decrease of the advance distance. There were seven surface cracks in G2 gully, including one tension type, three compression type and three shear type, with the maximum crack width of $79 \mathrm{~cm}$ and the maximum vertical displacement of $45 \mathrm{~cm}$. The maximum crack width of $79 \mathrm{~cm}$ and vertical displacement of $45 \mathrm{~cm}$ appeared in the toward-gully section of G2 under the 
effect of the back-gully section of G1. The development of surface cracks lagged behind the advance of working face, and the crack width and vertical displacement increased with the increase of lags behind distance.

\section{Discussion}

The previous research shows that the surface subsidence and deformation in the mining process have prominent discontinuous characteristics in space and time when the ratio of mining depth to mining thickness is less than 30 . The development law of surface cracks is closely related to the topography and geomorphology of gullies. When the shallow coal seam is mined in the surface blown-sand and loess gully region, with the direct roof fractured of the coal seam, the fracture zones in the overburden strata develop rapidly to the surface and form surface cracks.

Based on multilateral block structure [37-39] and mining slope theory [27], when the shallow coal seam is mined through double gullies terrain, the structure and force of the broken block of the gully are shown in Figure 8. With the integral contact between K1 and $\mathrm{K} 2$ blocks as the research object, the stress can be analyzed as follows:

$$
\left\{\begin{array}{l}
N=\frac{G \xi}{\tan \beta} \lambda \\
G=A r
\end{array}\right.
$$

Where $N$ is the extrusion stress in the horizontal direction along the multilateral block fracture surface; $G$ is the gravity stress of the multilateral block; $A$ is the multilateral block volume per thickness; $r$ is the volume weight; $\beta$ is the mean fracture angle of the multilateral block.

$$
\xi=\frac{h}{H}
$$

Where $\xi$ is the gully depth influence coefficient, $H$ is the depth of gully, $h$ is the mean mining thickness.

$$
\lambda=\frac{L}{H}=\frac{1}{\sin \alpha}
$$

Where $\lambda$ is the slope gradient influence coefficient, $H$ is the depth of gully, $L$ is the dip length of gully, $\alpha$ is the mean gully angle.

$$
f=k N \sin \beta
$$

Where $f$ is the friction stress of the multilateral block in the normal direction of the contact surface; $k$ is the soil lay friction coefficient, $k \approx 0.30$.

The development condition of surface cracks:

$$
G \geq N+f
$$

The formula (7) and (10) are brought into formula (11) to obtain the following:

$$
G \geq G \times \frac{h}{H} \times \cot \beta \times \frac{1}{\sin \alpha}+G \times \frac{h}{H} \times \cot \beta \times \frac{1}{\sin \alpha} \times \sin \beta \times k
$$

Intermediate parameter $\omega$ :

$$
\omega=\frac{h}{H} \times \cot \beta \times \frac{1}{\sin \alpha}
$$

The formula (13) is brought into formula (12) to

$$
1 \geq \omega \times(1+\sin \beta \times k)
$$

\begin{tabular}{|c|c|c|c|c|c|c|}
\hline \multirow{2}{*}{ Gully name } & \multicolumn{4}{|c|}{ The fracture parameters of overburden strata } & \multirow{2}{*}{$\omega \times(1+\sin \beta \times k)$} & \multirow{2}{*}{ Result } \\
\hline & The position in the gully & $\alpha /^{\circ}$ & $\beta /^{\circ}$ & $\omega$ & & \\
\hline \multirow{2}{*}{$\begin{array}{c}\text { G1 } \\
\text { (Secondary gully) }\end{array}$} & Toward-gully & 21 & 63 & 0.237 & $0.301(0.30)$ & $<1$ \\
\hline & Bottom-gully & 0 & 56 & I & I & I \\
\hline
\end{tabular}

From the formula (7) (14) and the experimental simulation results, the results of Table 4 can be obtained:

obtain the following:

Tab. 4 The fracture parameters of overburden strata in double gullies terrain 


\begin{tabular}{c|c|c|c|c|c|c}
\hline & Back-gully & 31 & 45 & 0.324 & $0.393(0.30)$ & $<1$ \\
\hline \multirow{4}{*}{$\begin{array}{c}\text { G2 } \\
\text { (Main gully) }\end{array}$} & Toward-gully & 17 & 67 & 0.145 & $0.185(0.30)$ & $<1$ \\
\cline { 2 - 7 } & Bottom-gully & 0 & 61.5 & $/$ & $/$ & $/$ \\
\cline { 2 - 7 } & Back-gully & 21 & 50.2 & 0.232 & $0.285(0.30)$ & $<1$ \\
\hline
\end{tabular}

Note: $\alpha \in(0,2 / \pi)$; in the bottom-gully section $\alpha=0, \sin \alpha$ is unmeaning.

According to the comparison between results in Table 4 and simulated experimental results, it can be seen that surface cracks developed in both G1 and G2 gullies when shallow coal seams are mined through double gullies terrain. The number and intensity of surface cracks increase with the decrease of $N+f$ value. The $\omega$ value increases with the increase of gully slope $\alpha$, so $\omega$ value is a positive correlation with slope $\alpha$. The calculated results of $\omega \times(1+\sin \beta \times k)$ are greater than $k$, the surface crack is leading the working face, and when it is less than $k$, the surface cracks lags the working face.

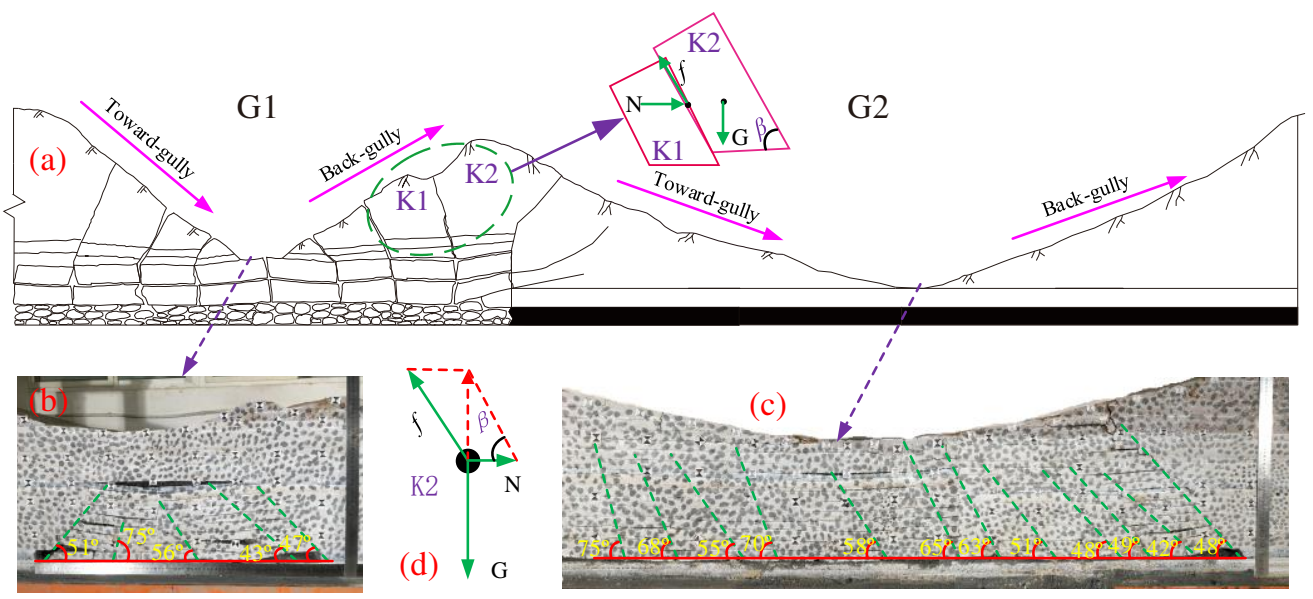

Fig.8 Failure and stress analysis model of overburden strata in double gullies terrain. (a) Multilateral block failure model of overburden strata. (b) Failure morphology of overburden strata in G1 gully. (c) Failure morphology of overburden strata in G2 gully.

(d) Stress analysis model of Multilateral block.

Based on the above simulation experimental results and theoretical analysis, it can be found that the development of surface cracks in double gullies terrain is affected by geological conditions, gully depth, slope, valley span and other factors. According to the theory of mining slip, and considering the basic parameters of the gully, the relative position function $T$ and discriminant conditions of surface cracks development in shallow coal seam mining through double gullies terrain can be obtained, as shown in formulas (15) and (16).

$$
T=H \tan ^{2} \alpha-\frac{L}{2} \tan \alpha+\frac{l}{3}
$$

Discriminant: $\begin{cases}T>0 ; & \text { advance } \\ T<0 ; & \text { lag }\end{cases}$

Where: $H$ is the gully depth, (m); $L$ is the gully span, $(\mathrm{m}) ; l$ is the distance between the two gullies edges, $(\mathrm{m}) ; \alpha$ is the upper (lower) slope angle of the double gullies terrain, $\left(^{\circ}\right) ; T$ is the relative position of the development of surface cracks.

From the discriminant conditions, it is known that when $T>0$, the relative position of surface crack development is advanced ahead of the working face, and when $T<0$, the relative position of surface crack development lags behind of the working face. Among these, $T$ value is comprehensively affected by gully depth, gully span and slope, $H$ and $L$ are the first 
power of $T$; however, $\tan \alpha$ is the second power of $T$. The $\tan \alpha$ is a monotone increasing function, and its value is positive $(\alpha \in(0,2 / \pi))$, so the gully slope is the main controlling factor affecting the relative position of surface cracks.

The basic parameters of double gullies terrain as listed in Table 1 can be calculated by the formula (15): when the working face is advanced to the secondary gully (G1 gully): in toward-gully section, $T=7.01>0$; in back-gully section, $T=0.82>0$. When the working face is advanced to the main gully (G2 gully): in toward-gully section, $T=-11.70<0$; in back-gully section, $T=-19.28<0$. According to the discriminant condition of formula (2), it is known that the surface cracks were leading the working face when the working face was passing through the G1 gully. However, the surface cracks lagged the working face when the working face was passing through the G2 gully.

From the experimental simulation phenomena and theoretical analysis results, it can be seen that: 1) in the $T>0$ conditions, with the increase of $T$ value, the crack width and vertical displacement increased, while the crack was leading distance decreases. Thus $T$ value is a positive correlation with crack width and vertical displacement of surface cracks, and it has a negative correlation with the leading distance of the surface crack. 2) in the $T<0$ conditions, the crack width and vertical displacement increase with the increase of $T$ value, and the crack lagging distance also increase. Moreover, $T$ value is a positive correlation with surface cracks leading distance, crack width and vertical displacement. With the gradual increase of $|T|$ value, the total number of single gully crack development and failure strength (crack width and vertical displacement) increase, and there is a positive correlation with them. The development characteristics of surface cracks and the calculation results of relative position function are shown in Table 5.

Tab. 5 The development law of surface cracks and the result of the relative position function

\begin{tabular}{|c|c|c|c|c|c|c|}
\hline \multirow[b]{2}{*}{ Gully name } & \multicolumn{4}{|c|}{ The development parameters of surface cracks } & \multirow{2}{*}{$\begin{array}{l}\text { The relative position } \\
\text { of surface cracks and } \\
\text { working face }\end{array}$} & \multirow[b]{2}{*}{$T$ value } \\
\hline & \multicolumn{2}{|c|}{$\begin{array}{l}\text { Development position } \\
\text { (distance of open-off cut )/m }\end{array}$} & $\begin{array}{c}\text { Crack } \\
\text { width } / \mathrm{mm}\end{array}$ & $\begin{array}{c}\text { Vertical } \\
\text { displacement } / \mathrm{mm}\end{array}$ & & \\
\hline \multirow{4}{*}{$\begin{array}{c}\text { G1 } \\
\text { (Secondary } \\
\text { gully) }\end{array}$} & 25 & Tourerd oully & 230 & 110 & Leading $5 \mathrm{~m}$ & \multirow{2}{*}{7.01} \\
\hline & 30 & lowara-guiny & 100 & 20 & Leading $10 \mathrm{~m}$ & \\
\hline & 60 & Bottom-gully & 70 & 10 & Leading $20 \mathrm{~m}$ & I \\
\hline & 93 & Back-gully & 90 & 20 & Leading $13 \mathrm{~m}$ & 0.82 \\
\hline \multirow{7}{*}{$\begin{array}{c}\mathrm{G} 2 \\
\text { (Main gully) }\end{array}$} & 160 & Toward-gully & 790 & 450 & Lagging $20 \mathrm{~m}$ & -11.70 \\
\hline & 190 & \multirow{3}{*}{ Bottom-gully } & 130 & 40 & Lagging $10 \mathrm{~m}$ & \multirow{3}{*}{ l } \\
\hline & 200 & & 40 & 10 & Lagging $10 \mathrm{~m}$ & \\
\hline & 215 & & 140 & 10 & Lagging $5 \mathrm{~m}$ & \\
\hline & 285 & \multirow{3}{*}{ Back-gully } & 360 & 190 & Lagging $15 \mathrm{~m}$ & \multirow{3}{*}{-19.28} \\
\hline & 335 & & 430 & 350 & Lagging $15 \mathrm{~m}$ & \\
\hline & 340 & & 550 & 390 & Lagging $20 \mathrm{~m}$ & \\
\hline
\end{tabular}

Note: $\alpha \in(0,2 / \pi)$; in the bottom-gully section $\alpha=0, \tan \alpha$ is unmeaning

\section{Conclusions}

The numerical simulation of the working face passing through the double gullies terrain was designed to obtain the variation law of overburden displacement field and the development law of surface cracks under "toward-gully section, bottom-gully section and back-gully section". The data from the 
simulation results were used to demonstrate the relative position between the surface cracks and working face. The similar material simulation was used to summarize the development position, shape and parameters of surface cracks under the condition of double gullies terrain. By combining with the engineering background, the relative position function and discrimination condition of surface crack development in shallow coal seam mining through double gullies terrain were firstly established, and the influence of double gullies parameters on the relative position of surface crack development was discussed. The following conclusions can be drawn based on the numerical simulation, similar material simulation and theoretical analysis results and discussion presented in the study.

(1) Numerical simulation and similar material simulation showed that when the working face passed through the G1 gully (secondary gully), there were four surface cracks, which of these surface cracks the maximum crack width was $23 \mathrm{~cm}$. The maximum vertical displacement was $11 \mathrm{~cm}$. Moreover, the G2 gully (main gully) had little influence on the development of surface cracks in G1 gully. When the working face passed through the G2 gully, there were seven surface cracks, whose maximum crack width and vertical displacement was $79 \mathrm{~cm}$ and $45 \mathrm{~cm}$, respectively. The interaction between the secondary gully (G1) and the main gully (G2) is excellent, which led to the appearance of the maximum crack width and vertical displacement in the toward-gully section of $\mathrm{G} 2$ and a broad range of surface cracks.

(2) The surface cracks at G1 gully was leading the working face during the working face of mining through the double gullies terrain. Meanwhile, with the increase of the maximum distance between the surface cracks and the working face, the crack width and vertical displacement showed a decreasing law.
The development of surface cracks at G2 gully lagged the working face. With the increase of lagging distance between the surface cracks and the working face, the crack width and vertical displacement increased.

(3) The slope of the gully is the main controlling factor affecting the relative position of the development of surface cracks. When the $T>0, T$ value is positively correlated with cracks width and vertical displacement of surface cracks and negatively correlated with the leading distance of surface cracks. when the $T<0, T$ value is positively correlated with leading distance, crack width and vertical displacement of surface cracks. $|T|$ value has a positive correlation with the total number of cracks developed in a single gully and the surface crack strength (crack width and vertical displacement).

\section{Data Availability}

The data used to support the findings of this study are included within the article.

\section{Conflicts of Interest:}

The authors declare no conflict of interest.

\section{Acknowledgements}

This work is supported by Key Laboratory of Exploration and Comprehensive Utilization of Mineral Resources, the National Natural Science Foundation of China (No. 41272388 and 40572155). The authors also thank the editor and anonymous reviewers very much for their valuable advice. All authors have agreed to the listing of authors.

\section{Author Contributions:}

Xueyang Sun and Mingjiao Lu designed the study; Mingjiao $\mathrm{Lu}$ carried out numerical simulation, analyzed the collected. Xueyang Sun, Enke Hou and Cheng Li acquired the funding, supervised the study; Mingjiao Lu and Yonggang Zhang reviewed and 
improved the manuscript draft. All authors have read and agreed to the published version of the manuscript.

\section{References}

1 G. B, R. G, Z. X, et al. Physical modelling of subsidence from sequential extraction of partially overlapping longwall panels and study of substrata movement characteristics. International Journal of Coal Geology. 2015; 140: 71-83.

2 N. CG, Á. F. MI, D. AM, et al. The new three-dimensional subsidence influence function denoted by nkg. International Journal of Rock Mechanics and Mining Sciences. 2005; 42(3): 372-387.

3 C. E, K. Şenol and M. C. Determination of underground mining induced displacements using GPS observations in Zonguldak Kozlu Hard Coal Basin. International Journal of Coal Geology. 2012; 89: 62-69.

4 Z. Dawei, W. Kan, B. Zhihui, et al. Formation and development mechanism of ground crack caused by coal mining: effects of overlying key strata. Bulletin of Engineering Geology and the Environment. 2017; 78(2): 1025-1044.

5 Y. Huang, F. Tian, Y. Wang, et al. Effect of coal mining on vegetation disturbance and associated carbon loss. Environmental Engineering Science. 2014; 73(5): 2329-2342.

6 M. Chi, D. Zhang, G. Fan, et al. Prediction of water resource carrying capacity by the analytic hierarchy process-fuzzy discrimination method in a mining area. Ecol. Indic. 2019; 96: 647-655.

7 D. Zhang, G. Fan, Y. Liu, et al. Field trials of aquifer protection in longwall mining of shallow coal seams in China. International Journal of Rock Mechanics and Mining Sciences. 2010; 47(6): 908-914.

8 J. Zhang and B. Shen. Coal mining under aquifers in China: a case study. International Journal of Rock Mechanics and Mining Sciences. 2004; 41(4): 629-639.

9 J. Na, X. Yang, G. Tang, et al. Population Characteristics of Loess Gully System in the Loess Plateau of China. Remote Sensing. 2020; 12(16): 2639.

10 J. Li, L. Xiong and G. a. Tang. Combined gully profiles for expressing surface morphology and evolution of gully landforms. Frontiers of Earth Science. 2019; 13(3): 551-562.

11 Z. Li, W. Zhang, Y. Aikebaier, et al. Sustainable Development of Arid Rangelands and Managing Rainwater in Gullies, Central Asia. Water. 2020; 12(9): 2533.
12 M. Reed and S. Kite. Peripheral gully and landslide erosion on an extreme anthropogenic landscape produced by mountaintop removal coal mining. Earth Surf. Processes Landforms. 2020; 45(9): 2078-2090.

13 H. B. Zhang. Effects of the Surface Cracks Caused by Coal Mining on Soil Characteristics and Wheat Growth in Huang-Huai-Hai Plain, China. Applied Ecology and Environmental Research. 2017; 15(4): 1777-1790.

14 X. Li, D. Wang, C. Li, et al. Numerical Simulation of Surface Subsidence and Backfill Material Movement Induced by Underground Mining. Advances in Civil Engineering. 2019; 2019: 1-17.

15 X.-f. Lv, H.-y. Zhou, A.-w. Wang, et al. Characteristics of Stress Transfer and Progressive Fracture in Overlying Strata due to Mining-Induced Disturbances. Advances in Civil Engineering. 2018; 2018: 1-13.

16 L. Sun, Y. Xie and H. Xiao. Numerical Analysis of Stress Fields and Crack Growths in the Floor Strata of Coal Seam for Longwall Mining. Mathematical Problems in Engineering. 2018; 2018: 1-12.

17 F. Wang, S. Chen, J. Xu, et al. New Method to Design Coal Pillar for Lateral Roof Roadway Based on Mining-Induced Stress: A Case Study. Advances in Civil Engineering. 2018; 2018: 1-13.

18 X. Wu, Y. Jiang, J. Wang, et al. A New Health Assessment Index of Tunnel Lining Based on the Digital Inspection of Surface Cracks. Applied Sciences. 2017; 7(5): 507.

19 Y. Xu, K. Wu, Z. Bai, et al. Theoretical analysis of the secondary development of mining-induced surface cracks in the Ordos region. Environmental Engineering Science. 2017; 76(20):

20 T. Liang, X. Liu, S. Wang, et al. Study on the Fractal Characteristics of Fracture Network Evolution Induced by Mining. Advances in Civil Engineering. 2018; 2018: 1-13.

21 D. Yin, S. Chen, B. Li, et al. Bed separation backfill to reduce surface cracking due to mining 
under thick and hard conglomerate: a case study. R Soc Open Sci. 2019; 6(8): 190880.

22 Z. Zhang, J. Xu, W. Zhu, et al. Simulation research on the influence of eroded primary key strata on dynamic strata pressure of shallow coal seams in gully terrain. International Journal of Mining Science and Technology. 2012; 22(1): 51-55.

23 M. Tao, Y. Yue, J.w. Ma, et al. Use of DC voltage fluctuation method to investigate real-time Mode I and Mode II subcritical crack growth behavior in gypsum rock. Engineering Fracture Mechanics. (2020): 107104.

24 T. Meng, X. J1, Li Xm, et al. Experimental study on the evolutional trend of pore structures and fractal dimension of low-rank clay rich coal subjected to a coupled thermo-hydro-mechanical-chemical environment. Energy. (2020): 117838.

25 F. Feng, S. Peng, W. Du, et al. The Assessment and Evolution of Water-Conducting Rules under the Influence of Mining-Induced Stress. Advances in Civil Engineering. 2018; 2018: 1-11.

26 S. Kang, Y. C. Wu and S. Ham. Singular Integral Solutions of Analytical Surface Wave Model with Internal Crack. Applied Sciences. 2020; 10(9): 3129.

27 H. Liu, K. Deng, S. Lei, et al. Mechanism of formation of sliding ground fissure in loess hilly areas caused by underground mining. International Journal of Mining Science and Technology. 2015;25(4):553-558.

28 Qiu L, Liu Z, Wang E, et al. Early-warning of rock burst in coal mine by low-frequency electromagnetic radiation, Engineering Geology. 2020, doi: 10.1016/j.enggeo.2020.105755.

29 M. Yibeltal, A. Tsunekawa, N. Haregeweyn, et al. Analysis of long-term gully dynamics in different agro-ecology settings. Catena. 2019; 179: 160-174.

30 A. D. Zegeye, E. J. Langendoen, T. S. Steenhuis, et al. Bank stability and toe erosion model as a decision tool for gully bank stabilization in sub humid Ethiopian highlands. Ecohydrol. Hydrobiol. 2020; 20(2): 301-311.

31 Z. Li, Y. Pang, Y. Bao, et al. Research on Surface Failure Law of Working Faces in Large Mining Height and Shallow Buried Coal Seam. Advances in Civil Engineering. 2020; 2020: 1-14.

$32 \mathrm{~J} . \mathrm{Li}, \mathrm{X} . \mathrm{Li}, \mathrm{C}$. Liu, et al. Dynamic Changes in Surface Damage Induced by High-Intensity Mining of Shallow, Thick Coal Seams in Gully Areas. Advances in Civil Engineering. 2020; 2020: 1-16.

33 W. Fangtian, T. Shihao, Z. Yanwei, et al. Ground pressure rules and roof control technology for the longwall mining of shallow seam beneath the gully topography. Journal of Mining \& Safety Engineering. 2015; 32(6): 877-882.

34 Z. Jie, L. Jingjing, Y. Tao, et al. Study on dynamic loading mechanism of mining in gully area of shallow coal seam. Journal of Mining \& Safety Engineering. 2019; 36(6): 1222-1227.

35 J. Zhao, J. Xiao, M. L. Lee, et al. Discrete element modeling of a mining-induced rock slide. Springerplus. 2016; 5(1): 1633.

36 H. En-ke, F. Dong, X. Xiao-shen, et al. Study on Development Characteristics and Treatment Methods of Mining Surface Cracks in shallow-buried Coal Seam Gully. Journal of China Coal Society. 2020, 10.13225/j.cnki.jccs.2020.0143

37 Z. Wang, G. Song and K. Ding. Study on the Ground Movement in an Open-Pit Mine in the Case of Combined Surface and Underground Mining. Advances in Materials Science and Engineering. 2020; 2020: 1-13.

38 G. Fan, D. Zhang and X. Wang. Mechanism of Roof Shock in Longwall Coal Mining under Surface Gully. Shock Vib. 2015; 2015: 1-8.

39 J. Li and C. Liu. Formation Mechanism and Reduction Technology of Mining-Induced Fissures in Shallow Thick Coal Seam Mining. Shock Vib. 2017; 2017: 1-14. 


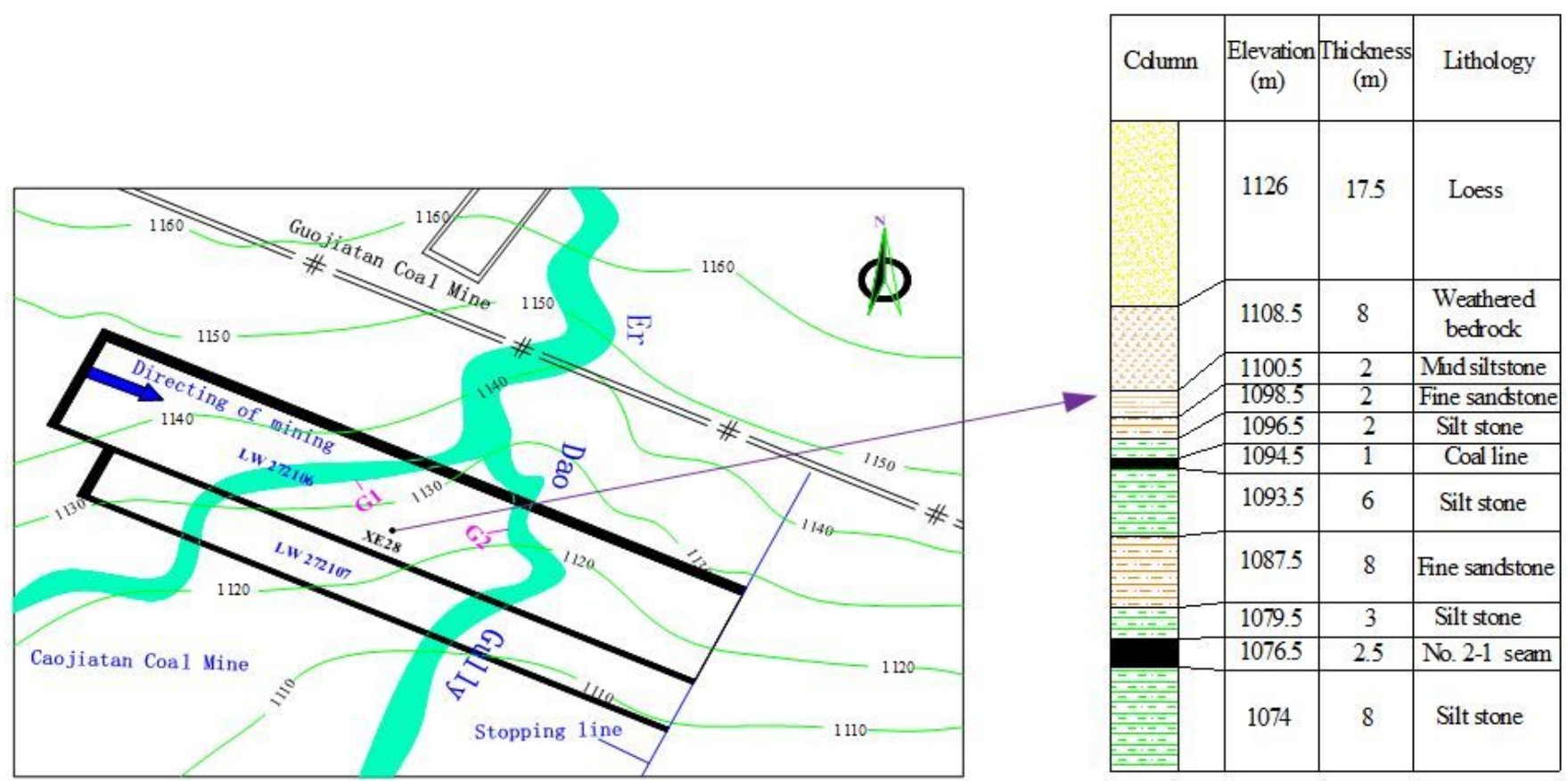

\section{Figure 1}

Plan view of the local panel layout and drill column

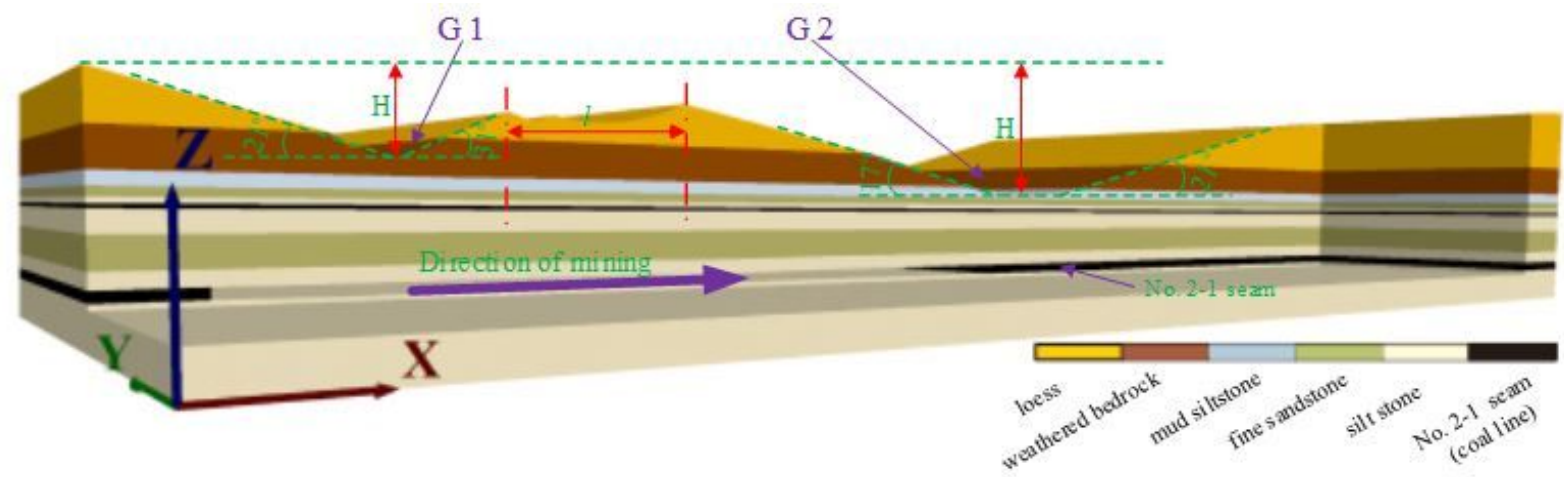

Figure 2

The numerical simulation model 
$\mathrm{Z}$ displacement $/ \mathrm{m}$

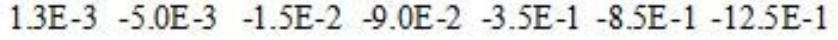

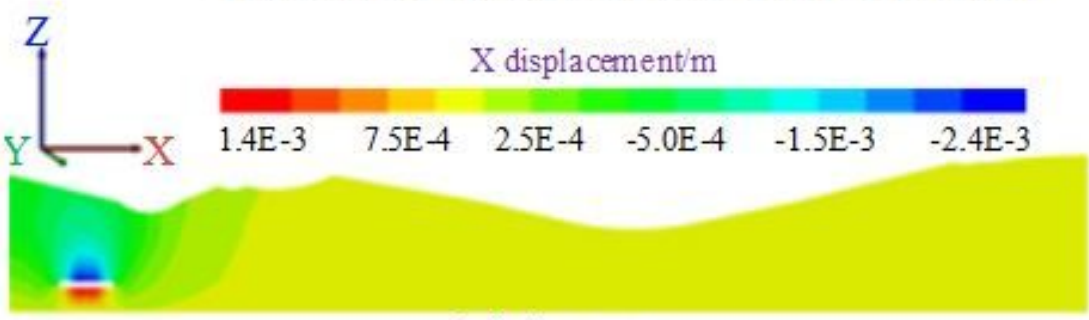

Z displacement

Surface cracks area

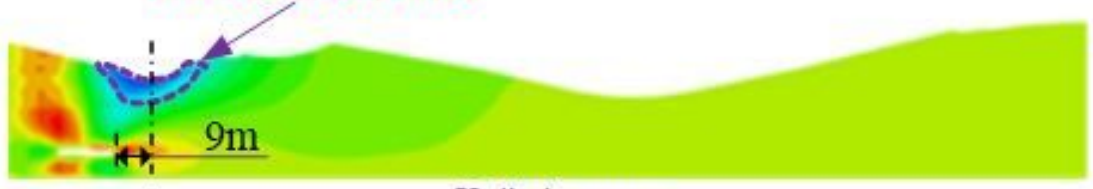

$\mathrm{X}$ displacement

(a)

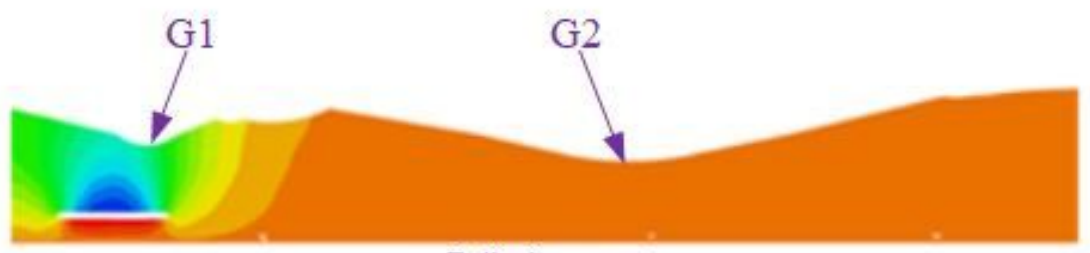

$\mathrm{Z}$ displacement

Surface cracks area

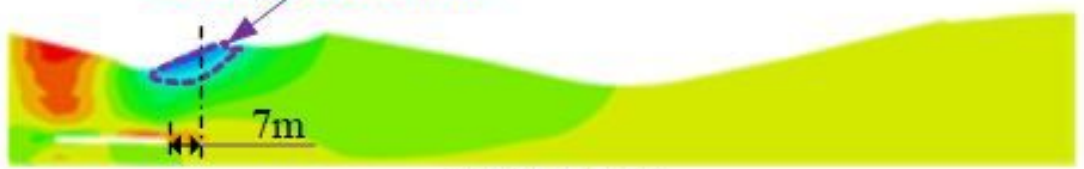

$\mathrm{X}$ displacement

(b)

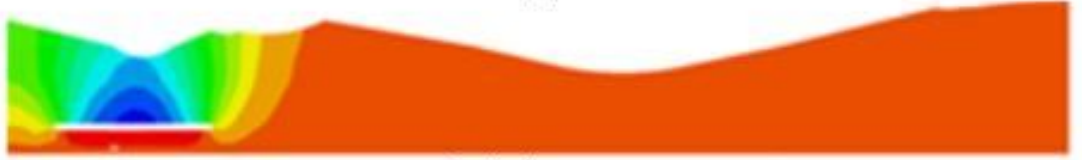

Z displacement

Surface cracks area

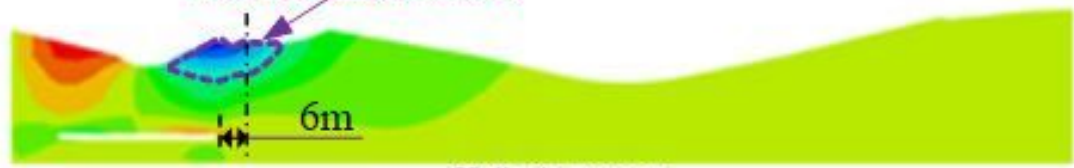

$\mathrm{X}$ displacement

(c)

\section{Figure 3}

Displacement cloud map of overburden strata passing through G1 gully. (a) Toward-gully section. (b) Bottom-gully section. (c) Back-gully section. 


\section{3. $3 \mathrm{E}-3-5.0 \mathrm{E}-3-8.5 \mathrm{E}-2-5.0 \mathrm{E}-1-9.5 \mathrm{E}-1-15.5 \mathrm{E}-1-21.5 \mathrm{E}-1$}

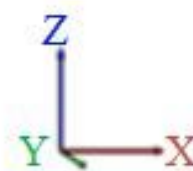

$\mathrm{X}$ displacement $/ \mathrm{m}$

\section{$\begin{array}{llllll}5.0 \mathrm{E}-3 & 3.0 \mathrm{E}-3 & 1.0 \mathrm{E}-3 & -3.0 \mathrm{E}-3 & -4.0 \mathrm{E}-3 & -5.0 \mathrm{E}-3\end{array}$}

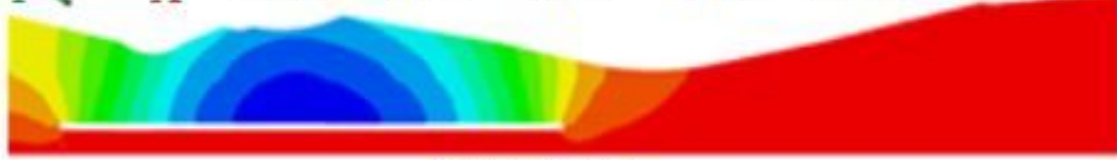

Z displacement

Surface cracks area

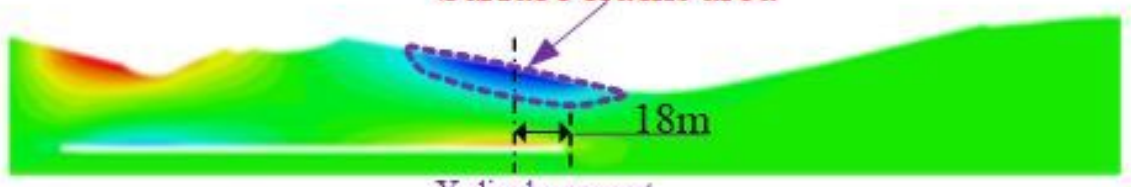

$\mathrm{X}$ displacement

(a)

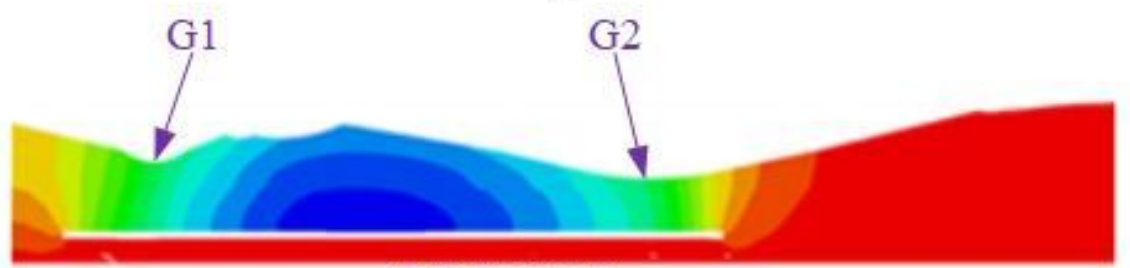

$\mathrm{Z}$ displacement

Surface cracks area

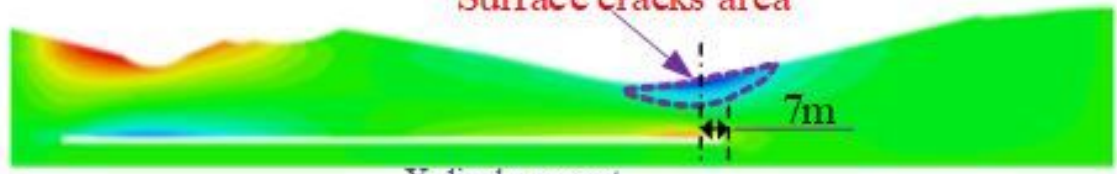

$\mathrm{X}$ displacement

(b)

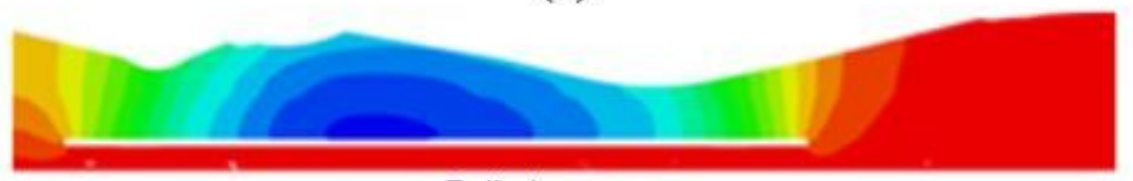

Z displacement

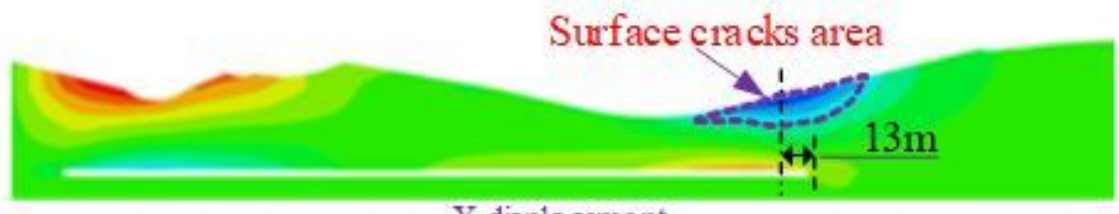

$\mathrm{X}$ displacement

(c)

\section{Figure 4}

Displacement cloud map of overburden strata passing through G2 gully. (a) Toward-gully section. (b) Bottom-gully section. (c) Back-gully section. 


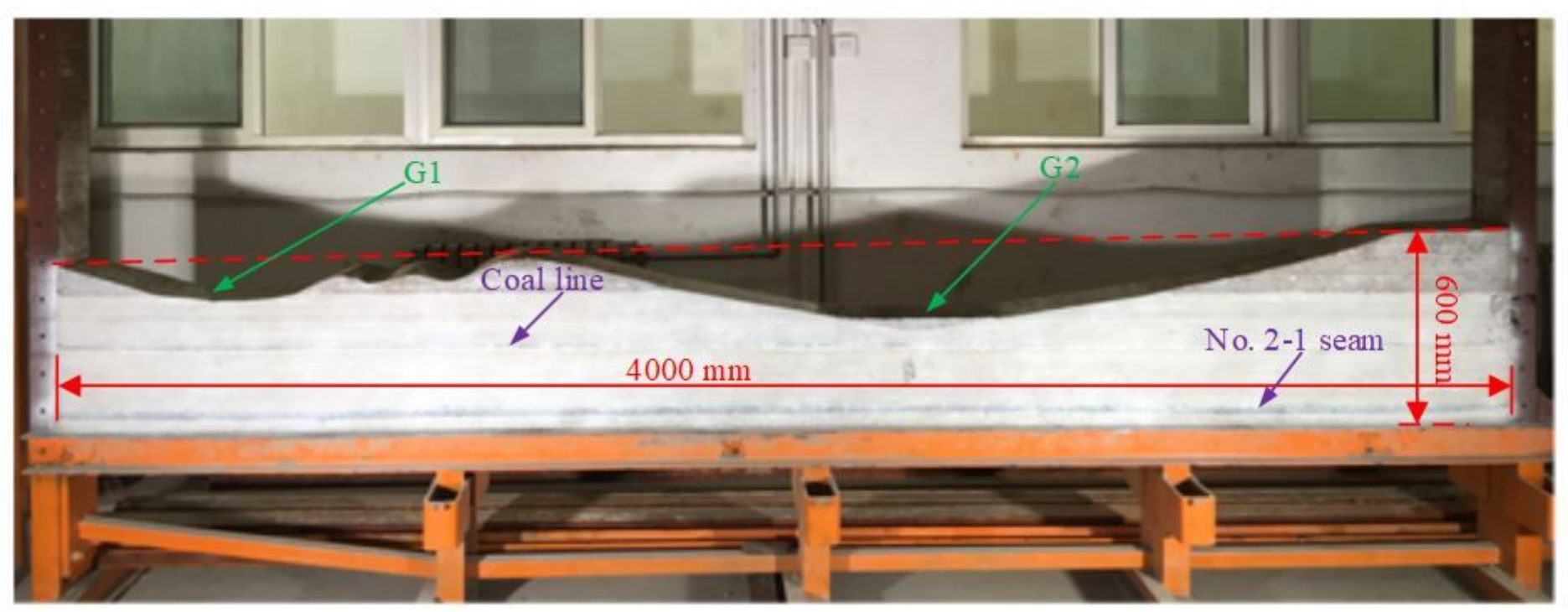

Figure 5

Similar material simulation model 


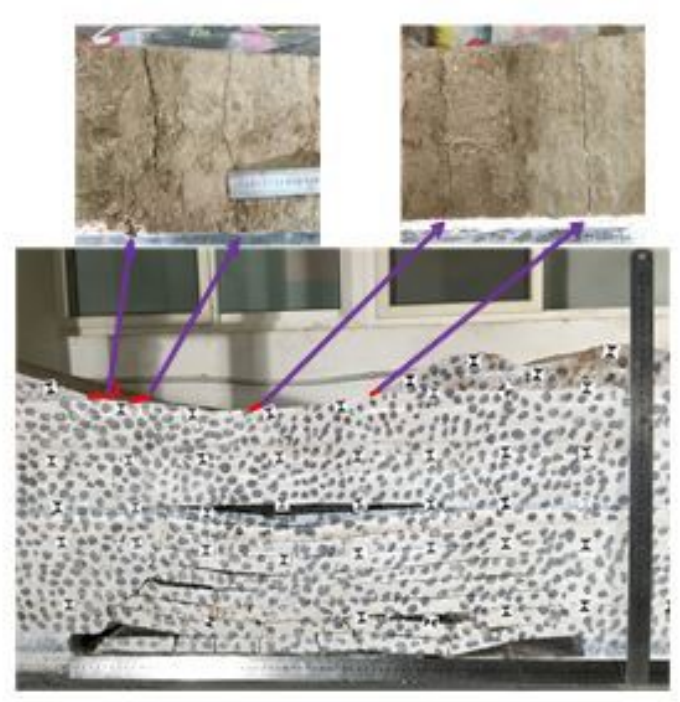

(a)
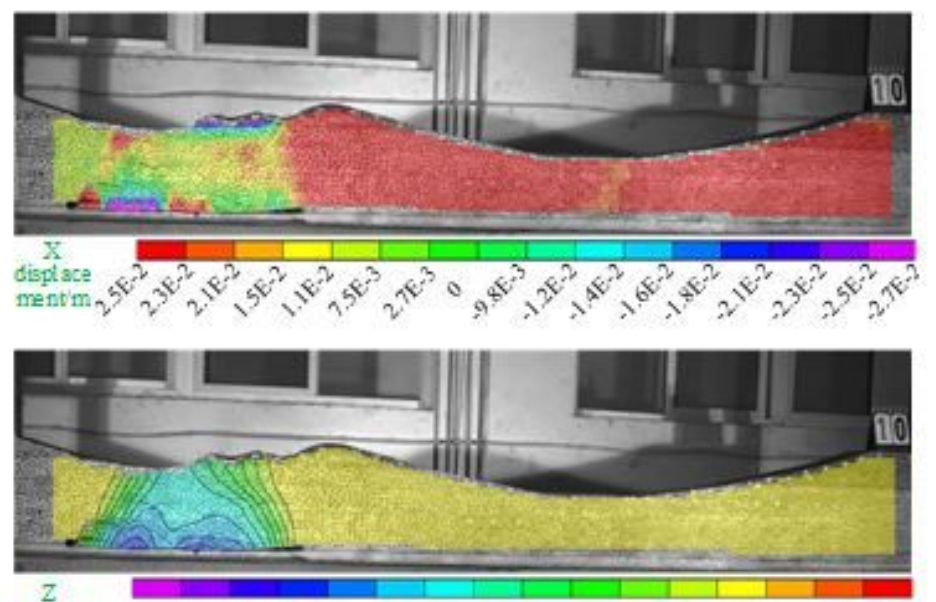

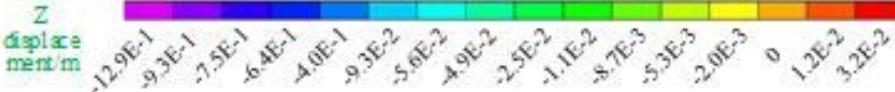

(b)

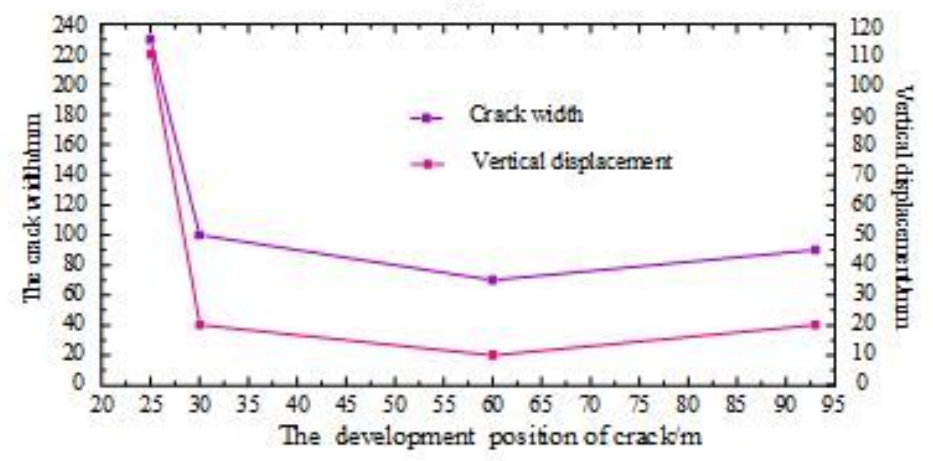

(c)

\section{Figure 6}

Morphology and parameters of surface cracks passing through G1 gully. (a) Development morphology of surface cracks. (b) Displacement cloud map of overburden strata (VIC-3D). (c) Development position of surface cracks. 


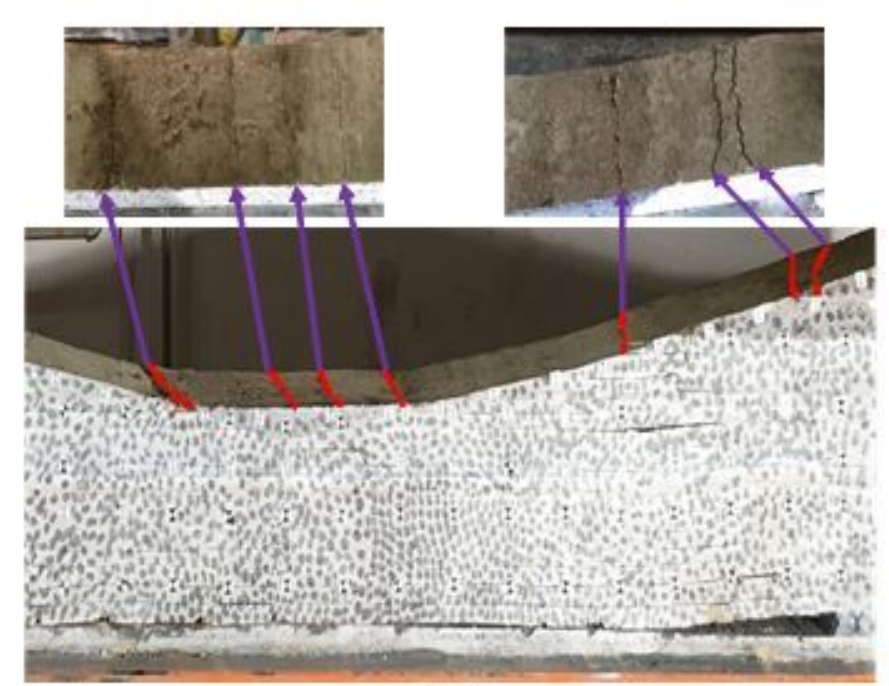

(a)
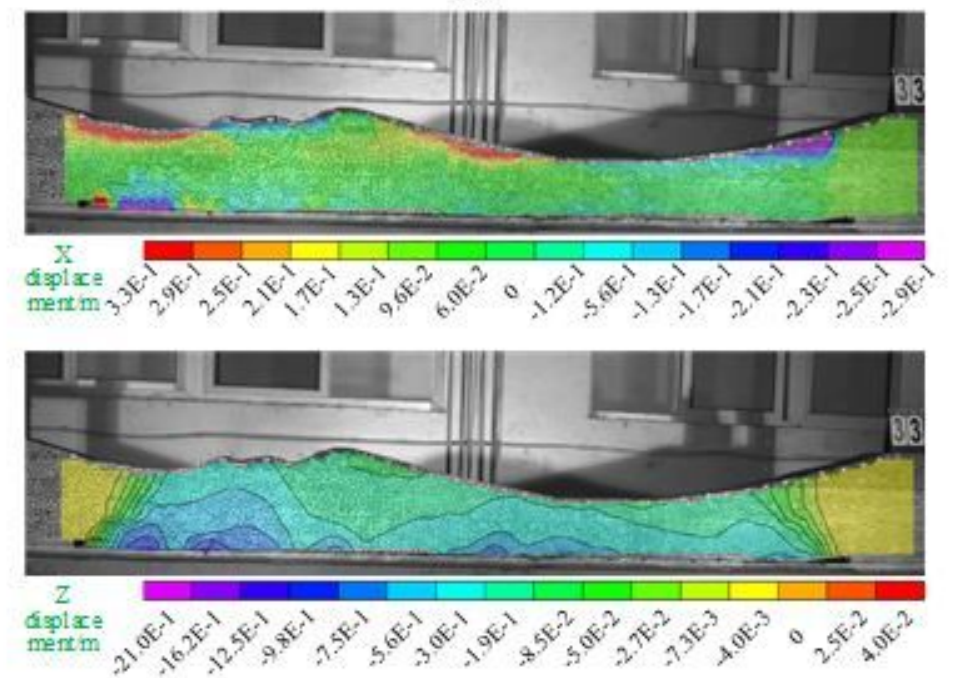

(b)

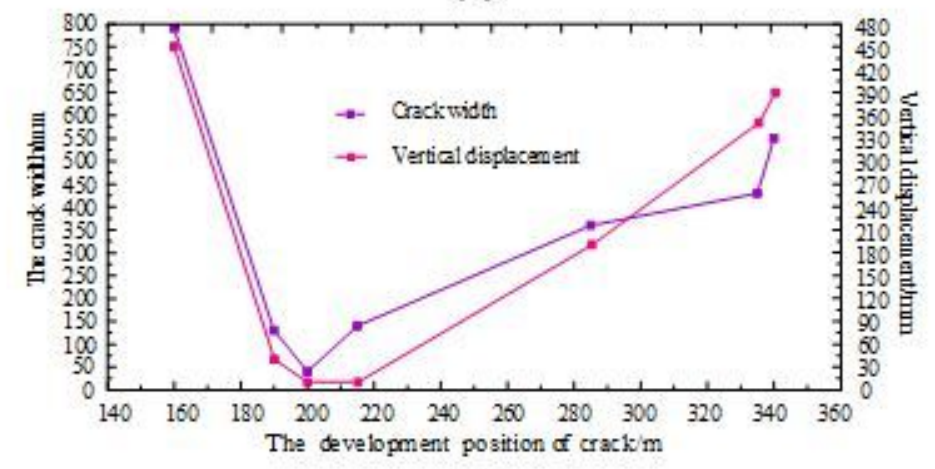

(c)

\section{Figure 7}

Morphology and parameters of surface cracks passing through G2 gully. (a) Development morphology of surface cracks (VIC-3D). (b) Displacement cloud map of overburden strata. (c) Development position of surface cracks. 


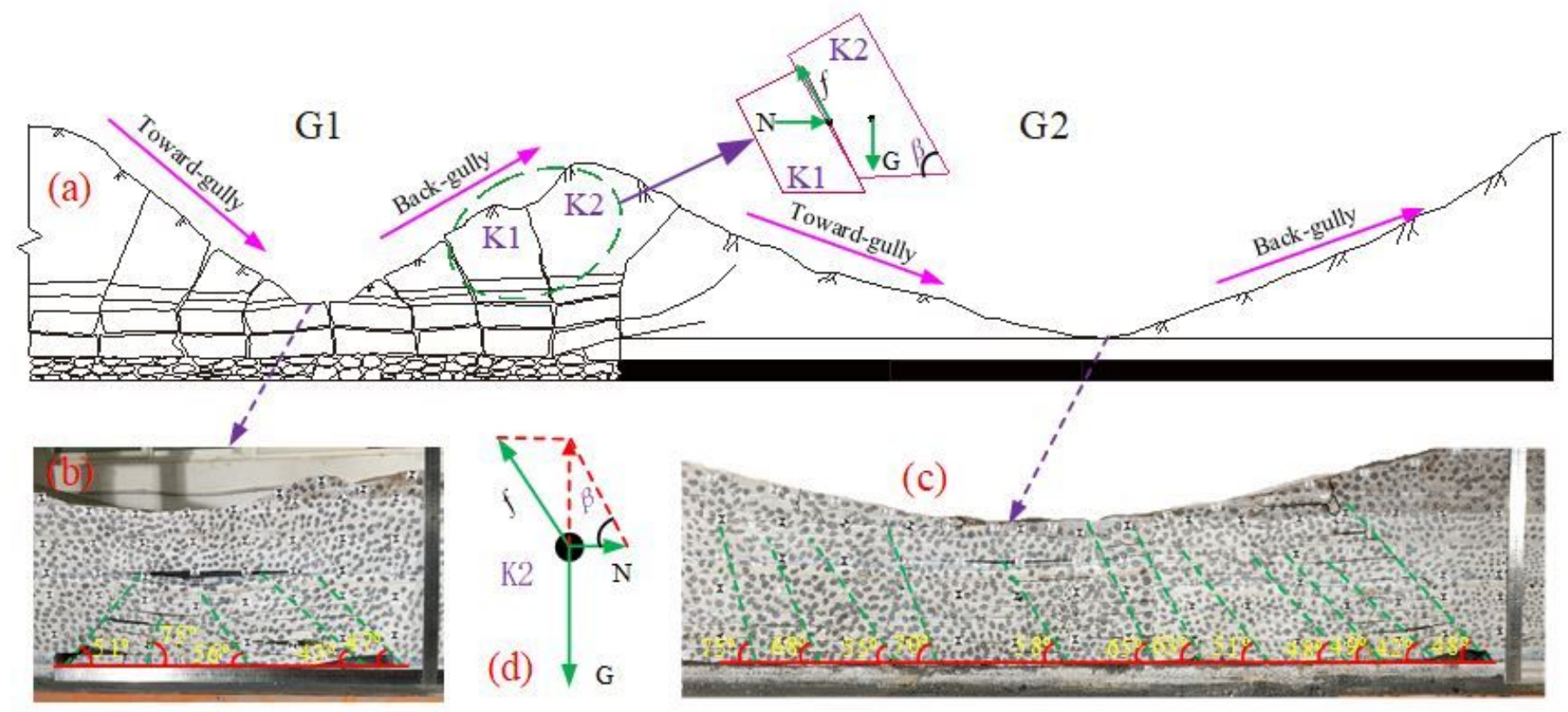

Figure 8

Failure and stress analysis model of overburden strata in double gullies terrain. (a) Multilateral block failure model of overburden strata. (b) Failure morphology of overburden strata in G1 gully. (c) Failure morphology of overburden strata in G2 gully. (d) Stress analysis model of Multilateral block. 